\title{
BETONARME KOLONLARIN SARGISIZ ve SARGILI BETON DAYANIMININ ANALITIK OLARAK ARAŞTIRILMASI
}

\author{
${ }^{1}$ S. Bahadır YÜKSEL, ${ }^{2}$ Saeid FOROUGHİ \\ 1,2 Konya Teknik Üniversitesi, Mühendislik ve Doğa Bilimleri Fakültesi, İnşaat Mühendisliği Bölümü, Konya, \\ TÜRKIYY \\ 1sbyuksel@ktun.edu.tr, 2saeid.foroughi@yahoo.com
}

(Geliş/Received: 10.01.2019; Kabul/Accepted in Revised Form: 05.03.2019)

ÖZ: Betonarme kolonlar taşıyıcı sistemlerin moment aktaran kritik yapısal sistemleridir ve yeterli dayanım ve süneklikte tasarlanmalıdır. Betonarme kolonların sargı donatısı özellikle depreme maruz kaldıkları durumlarda sargı etkisi ile kolonların dayanım ve sünekliğinin artırmasında önemli rol oynar. Betonarme kolonlarda sargı donatısı boyuna donatının yerel burkulmasını geciktirmek, kesme kuvvetine karşı koymak, ani kesme kırılmasını önlemek ve sargı etkisi ile dayanım ve sünekliği artırmak için kullanılır. Sismik yüklere maruz kalan betonarme elemanların davranışı, esas olarak betonun nihai dayanımına ve sünekliğine bağlıdır. Bu parametreleri araştırmak için değişik geometride betonarme kolon modelleri tasarlanmıştır. Sargı donatı çapının ve sargı donatı aralığının betonarme kolon modellerinin davranışına etkisi analitik olarak araştııılmıştır. Sargı donatıları ile sarılmış betonarme kolon modellerinin davranışını araştırmak için literatüre sunulmuş olan analitik modeller kullanılmıştır. Farklı parametrelerde tasarlanan sargılı kolon modelleri için gerilme-birim şekil değiştirme eğrileri çizilmiş ve elde edilen sonuçlar karşılaştırılarak yorumlanmıştır.

Anahtar Kelimeler: Sargılı beton, Sargı donatısı, Sargılı beton dayanımı, Süneklik, Gerilme-şekil değiştirme ilişkileri

\section{Analytical Investigation of Confined and Unconfined Concrete Strength of Reinforced Concrete Columns}

\begin{abstract}
Reinforced concrete columns are the critical members of moment-resisting structural systems and have to be designed adequately in strength and ductility. Transverse reinforcement in concrete columns plays an important role in the improvement of strength and ductility of columns, especially when they are subjected to severe ground motion. Transverse reinforcement in concrete columns can be used to delay the local buckling of longitudinal bars, resist shear forces, avoid the sudden shear failure and confine the concrete to improve the strength and ductility. The behavior of reinforced concrete members subjected to seismic loads is mainly based on the ultimate strength of concrete and its ductility. Reinforced concrete column models having different cross-section have been designed to investigate these parameters. The effects of the transverse reinforcement spacing and transverse reinforcement diameter on the behavior of column models have been analytically investigated. Previously proposed analytical models were used to investigate the behavior of the reinforced confined column models. Stress-strain relationships were obtained for the confined concrete columns and the obtained results were compared and interpreted.
\end{abstract}

Key Words: Confined concrete, Confining reinforcement, Confined concrete strength, Ductility, Stress-strain relationship 


\section{GİRİŞ (INTRODUCTION)}

Meydana gelen yıkıcı depremler, mevcut binaların deprem performanslarının belirlenmesi konusundaki çalışmaların önemini arttırmıştır. Şiddetli depremlerde yapıların depreme dayanıklı performans tasarımı ve analizi; doğrusal ve doğrusal olmayan tasarım ve analiz olarak iki farklı davranış olarak ayrılmaktadır. Doğrusal elastik olmayan davranışın daha iyi anlaşılabilmesi için sargısız ve sargılı beton modelleri, gerilme-şekil değiştirme bağıntıları ve kesitlerin sünekliklerinin hesaplanması gereklidir. Betonarme yapısal elemanların kesit davranışı, kesitte kullanılan malzeme, kesitin geometrisi ve kesite etki eden yüklemelere bağlıdır. Yapıların depreme karşı dayanıklı olabilmesi için, yapısal elemanların yeterli dayanımlarının yanında bu dayanımlarını sürdürebilmeleri için elemanların sünek olmaları gerekmektedir. Yapısal elemanların yeterli süneklikte olabilmelerini sağlamak için sargı donatısı kullanılır. Sargı donatılı betonarme yapısal elemanların gerilme-şekil değiştirme davranışı, sargı donatısız betonarme yapısal elemanlarınkine göre farklılık göstermektedir. (Foroughi, 2018).

Betonarme yapıların ve yapısal elemanların davranışı, elemanların gerilme-şekil değiştirme ve deformasyon özelliklerine bağlı olarak değişir. Sargılı betonun eksenel basınç gerilmeleri altındaki davranışının belirlenmesinde farklı araştırmacılar tarafından çok sayıda deneysel ve kuramsal çalışma ve davranış modeli önerilmiştir. Bu çalışmada sargılı betonarme elemanlar için Mander ve diğ. (1988a), Saatçioğlu ve Ravzi (1992) tarafından sargılı ve sargısız betonarme elemanlar için önerilmiş olan eksenel yük altındaki davranış modelleri incelenmiştir. Mander ve diğ. (1988a), Saatçioğlu ve Ravzi (1992) davranış modelleri kullanılarak sargılı ve sargısız betonarme yapısal elemanların davranışı dikkate alınarak sargılı beton basınç dayanımı analitik olarak araştırılmıştır. Değişik geometride toplam 33 adet betonarme kolon modeli tasarlanmıştır. Betonarme kolon modellerinin tasarımında Türkiye Bina Deprem Yönetmeliği (2018)'de verilen hükümler dikkate alınmıştır. Değişik geometrilerde tasarlanan her betonarme kolon modeli için üç farklı sargı donatı çapı, her sargı donatı çapı için üç farklı sargı donatı aralığı olmak üzere toplam 99 adet betonarme kolon kesit modelinin sargılı beton basınç dayanımları araştırılmıştır. Sargılı beton basınç dayanımları hesaplanarak kesitlerin gerilme-şekil değiştirme ilişkileri elde edilmiştir. Farklı özelliklerde sargılı beton modellerinde sargılı beton basınç dayanımları hesaplanarak gerilme- birim şekil değiştirme ilişkileri elde edilmiş ve elde edilen sonuçlar farklı parametrelere göre karşılaştırılarak yorumlanmıştır. Boyuna donatı çapı, sarg1 donatı çapı ve sarg1 donatısı aralığının değişiminin betonarme kesitlerin davranışına etkisi Mander ve di ̆. (1988a) ve Saatçioğlu ve Ravzi (1992) modeline göre incelenmiştir. Mander ve diğ. (1988a) ve Saatçioğlu ve Ravzi (1992) modelinden elde edilen sonuçlar karşılaştırılmıştır.

\section{GERILLME- ŞEKİL DEĞİŞTİRME BAĞINTILARI (STRESS-STRAIN RELATIONSHIP)}

Deprem etkileri altındaki betonarme yapısal elemanlar büyük şekil değiştirmelere maruz kaldıklarında yük taşıma kapasitelerini sargı donatısı arasında kalan çekirdek betonun davranışı belirler. Sargı donatıları ile sarılmış betonarme yapısal elemanların davranışını araştırmak için Mander ve diğ. (1988a), Saatçioğlu ve Ravzi (1992) modeli kullanılmıştır. Tasarlanan betonarme kolon modellerinde araştırılan ve dikkate alınan parametreler sırasıyla sargı donatı çapı ve aralığı, boyuna ve sargı donatısının kesitteki dağılımı ve yerleşim planı, kesit geometrisi ve boyutlarıdır.

\section{Sargılı Beton için Mander Modeli (Mander Model for Confined Concrete)}

Mander beton modeli, dairesel, spiral, dikdörtgen sargı donatılı, dairesel, kare veya dikdörtgen kesitli betonarme yapı elemanların monotonik veya çevrimsel yükler altındaki davranışlarını tanımlamak amacıyla geliştirilmiştir. Sargılı beton davranışı ile ilgili geliştirilen bu model, Mander (1983), Mander ve diğ. (1988a) ve Mander ve diğ. (1988b) tarafından yapılan çalışmalara dayanmaktadır. Mander ve diğ. (1988a) dairesel, spiral, dikdörtgen sargı donatıya sahip sarılmış betonarme kesitler için gerilme-birim şekil değiştirme bağıntısı önermiştir. 
Mander modeline göre kare ve dikdörtgen kesitler için sargılı beton basınç dayanımı (Confined concrete strength for square and rectangular sections according to Mander model)

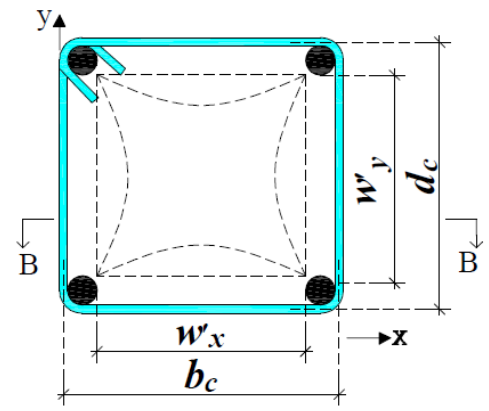

Kesit $A-A$

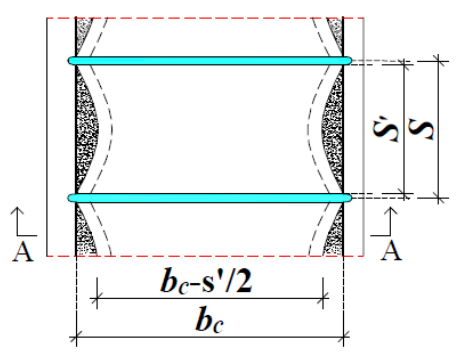

Kesit B-B

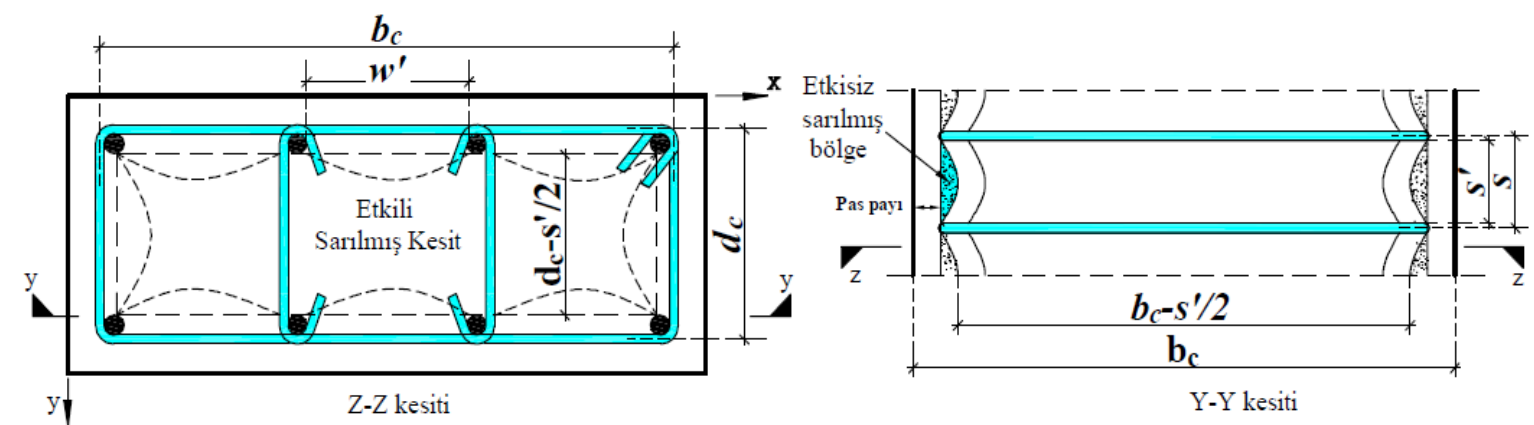

Şekil 1. Sargı donatılı kesitlerde etkin sarılmış beton çekirdek alanı

Figure 1. Effectively confined core for rectangular hoop reinforcement

Sargı betonun net en-kesit alanı $\left(\mathrm{A}_{\mathrm{cc}}\right)$ Denklem 1 ile hesaplanmaktadır.

$$
A_{c c}=b_{c} d_{c}\left(1-\rho_{c c}\right)
$$

Etkili sargı bölgesi alanı; toplam etkisiz sargı bölgesi olan parabollerin alanından çıkararak $\left(\mathrm{A}_{\mathrm{i}}\right)$ Denklem 2 ile hesaplanmaktadir.

$$
\mathrm{A}_{\mathrm{i}}=\frac{\sum_{\mathrm{i}}^{\mathrm{n}}\left(\mathrm{w}_{\mathrm{i}}^{\prime}\right)^{2}}{6}
$$

Etkili olarak sarılan kesit alanı $\left(\mathrm{A}_{\mathrm{e}}\right)$ Denklem 3 ile hesaplanmaktadır.

$$
A_{e}=\left(b_{c} d_{c^{-}} \sum_{i}^{n} \frac{\left(w_{i}^{\prime}\right)^{2}}{6}\right)\left(1-\frac{S^{\prime}}{2 b_{c}}\right)\left(1-\frac{S^{\prime}}{2 d_{c}}\right)
$$

Etkili olarak sarılmış olan alanın $\left(A_{e}\right)$, sargılı beton en-kesit alanına $\left(A_{c c}\right)$ oranı $\left(k_{e}\right)$ olarak sargı etkisi katsayısı, dikdörtgen sargı donatılı kesitler için Denklem 4 ile hesaplanmaktadır.

$$
\mathrm{k}_{\mathrm{e}}=\frac{\mathrm{A}_{\mathrm{e}}}{\mathrm{A}_{\mathrm{cc}}}=\frac{\left(1-\sum_{\mathrm{i}}^{\mathrm{n}} \frac{\left(\mathrm{w}_{\mathrm{i}}^{\prime}\right)^{2}}{6 \mathrm{~b}_{\mathrm{c}} \mathrm{d}_{\mathrm{c}}}\right)\left(1-\frac{\mathrm{S}^{\prime}}{2 \mathrm{~b}_{\mathrm{c}}}\right)\left(1-\frac{\mathrm{S}^{\prime}}{2 \mathrm{~d}_{\mathrm{c}}}\right)}{\left(1-\rho_{\mathrm{cc}}\right)}
$$

Etkin sarg1 gerilmesini ifade etmek için $A_{s x}$ ve $A_{s y}$ kesit üzerinde $x$ ve y yönlerinde kullanılan sarg1 donatılarının en-kesit alanı olmak üzere, $\rho_{x}$ ve $\rho_{y}$ bu yönlerde donatı oranı Denklem 5, 6 ve 7 ile hesaplanmaktadir.

$$
\rho_{x}=\frac{A_{s x}}{s . d_{c}}, \rho_{y}=\frac{A_{s y}}{s . b_{c}}, \quad \rho_{s}=\rho_{x}+\rho_{y}
$$

$x$ ve y yönünde betona uygulanan etkili yanal basınçları aşağıdaki denklemlerden hesaplanmaktadır.

$$
\begin{aligned}
& f_{l x}=\frac{A_{s x}}{s \cdot d_{c}} \cdot f_{y h}=\rho_{x} \cdot f_{y h}, f_{l y}=\frac{A_{s y}}{s \cdot b_{c}} \cdot f_{y h}=\rho_{y} \cdot f_{y h} \\
& f_{l x}^{\prime}=k_{e} \frac{A_{s x}}{s \cdot d_{c}} f_{y h}=k_{e} \cdot f_{l x}, f_{l y}^{\prime}=k_{e} \frac{A_{s y}}{s \cdot b_{c}} f_{y h}=k_{e} \cdot f_{l y}
\end{aligned}
$$


Mander modeline göre dairesel kesitler için sargılı beton basınç dayanımı (Confined concrete strength for circular concrete sections according to Mander model)

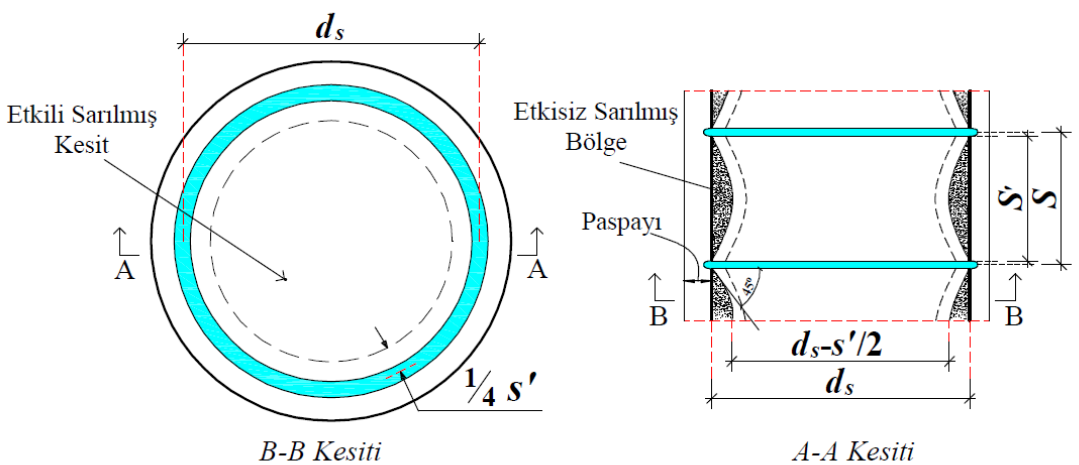

Şekil 2. Sargı donatılı kesitlerde etkin sarılmış beton çekirdek alanı Figure 2. Effectively confined core for circular hoop reinforcement

Dairesel kesitler için sargılı betonun net en-kesit alanı $\left(\mathrm{A}_{\mathrm{cc}}\right)$ Denklem 8 ile hesaplanmaktadır.

$$
\mathrm{A}_{\mathrm{cc}}=\frac{\pi}{4} \mathrm{~d}_{\mathrm{s}}^{2}\left(1-\rho_{\mathrm{cc}}\right)
$$

Etkili olarak sarılan kesitin iki sargı donatısının net aralığının ortasında etkili olarak sarılan kesit alanı ( $\left.A_{e}\right)$ Denklem 9 ile hesaplanmaktadır. Burada s' düşey doğrultuda iki spiral veya dairesel net aralığı, $d_{s}$, ise çekirdek çapıdır.

$$
\mathrm{A}_{\mathrm{e}}=\frac{\pi}{4}\left(\mathrm{~d}_{\mathrm{s}}-\frac{\mathrm{s}^{\prime}}{2}\right)^{2}=\frac{\pi}{4} \mathrm{~d}_{\mathrm{s}}^{2}\left(1-\frac{\mathrm{s}^{\prime}}{2 \mathrm{~d}_{\mathrm{s}}}\right)^{2}
$$

Dairesel etriyeler için sargı etkisi katsayısı Denklem 10 ile hesaplanmaktadır.

$$
\mathrm{k}_{\mathrm{e}}=\frac{\mathrm{A}_{\mathrm{e}}}{\mathrm{A}_{\mathrm{cc}}}=\frac{\left(1-\frac{\mathrm{s}^{\prime}}{2 \mathrm{~d}_{\mathrm{s}}}\right)^{2}}{\left(1-\rho_{\mathrm{cc}}\right)}
$$

Benzer şekilde dairesel spiraller için de Denklem 11 ve 12 ile hesaplanmalıdır.

$$
k_{e}=\frac{A_{e}}{A_{c c}}=\frac{\left(1-\frac{s^{\prime}}{2 d_{s}}\right)}{\left(1-\rho_{c c}\right)}
$$

Spiral veya dairesel etriyelerle sarılmış çekirdek betona uygulanan yanal sargı basıncı aşağıdaki denklemden hesaplanmaktadir.

$$
2 \mathrm{f}_{\mathrm{yh}} \mathrm{A}_{\mathrm{sp}}=\mathrm{f}_{1} \mathrm{~s} \mathrm{~d}_{\mathrm{s}}
$$

Burada $\mathrm{f}_{\mathrm{yh}}$; sarg1 donatısının akma dayanımı, $\mathrm{A}_{\mathrm{sp}}$; sarg1 donatı çubuğunun alanı, $\mathrm{f}_{1}$; betona uygulanan yanal sargı basıncı ve s; spiral veya dairesel etriyelerin merkezinden merkezine ölçülen mesafedir. $\rho_{\mathrm{s}}$; sarg1 donatı hacminin çekirdek betonunu hacmine oranı Denklem 13 ile hesaplanmaktadır.

$$
\rho_{\mathrm{s}}=\frac{\mathrm{A}_{\mathrm{sp}} \pi \mathrm{d}_{\mathrm{s}}}{\frac{\pi}{4} \mathrm{~d}_{\mathrm{s}} \mathrm{s}}=\frac{4 \mathrm{~A}_{\mathrm{sp}}}{\mathrm{d}_{\mathrm{s}} \mathrm{s}}
$$

Denklem (12) ve denklem (13)'ten;

$$
\mathrm{f}_{\mathrm{l}}=\frac{1}{2} \rho_{\mathrm{s}} \mathrm{f}_{\mathrm{yh}}
$$

Dairesel kesitli kolonlarda betona uygulanan etkili yanal basınç değeri Denklem 15 ile hesaplanacaktır.

$$
f_{l}^{\prime}=\frac{1}{2} k_{e} \rho_{s} f_{y h}
$$

Sargılı beton basınç dayanımı $\left(\mathrm{f}_{\mathrm{cc}}^{\prime}\right)$ için Denklem 16 kullanılmaktadır.

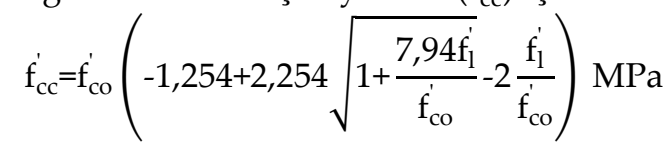

Sarg1lı betonda beton basınç gerilmesi $\mathrm{f}_{\mathrm{c}}$, basınç birim şekil değiştirmesi $\varepsilon_{\mathrm{c}}$ 'nin fonksiyonu olarak Denklem 17 ile verilmektedir. Aşağıdaki bağlantılarda $\mathrm{f}_{\mathrm{c}}$ ve $\varepsilon_{\mathrm{c}}$ sırasıyla herhangi bir andaki beton dayanımını ve 
karşılık gelen şekil değiştirmeyi temsil etmektedir. Monotonik olarak yüklenen betonda oluşacak gerilme aşağıdaki bağıntılar ile bulunabilir.

$$
\mathrm{f}_{\mathrm{c}}=\frac{\mathrm{f}_{\mathrm{cc}}^{\prime} \times \mathrm{r}}{\mathrm{r}-1+\mathrm{x}^{\mathrm{r}}}
$$

Normalize edilmiş beton birim şekil değiştirmesi x ile $\mathrm{r}$ değişkenine ilişkin bağıntılar Denklem 18, 19, 20,

21 ve $22^{\prime}$ de verilmiştir.

$$
\begin{aligned}
& \mathrm{x}=\frac{\varepsilon_{\mathrm{c}}}{\varepsilon_{\mathrm{cc}}} \\
& \varepsilon_{\mathrm{cc}}=\varepsilon_{\mathrm{co}}\left[1+5\left(\frac{\mathrm{f}_{\mathrm{cc}}^{\prime}}{\mathrm{f}_{\mathrm{co}}^{\prime}}-1\right)\right] \\
& \mathrm{r}=\frac{\mathrm{E}_{\mathrm{c}}}{\mathrm{E}_{\mathrm{c}}-\mathrm{E}_{\mathrm{sec}}} \\
& \mathrm{E}_{\mathrm{c}}=5000 \sqrt{\mathrm{f}_{\mathrm{co}}^{\prime}} \mathrm{MPa} \\
& \mathrm{E}_{\mathrm{sec}}=\frac{\mathrm{f}_{\mathrm{cc}}}{\varepsilon_{\mathrm{cc}}}
\end{aligned}
$$

Betondaki en büyük birim şekil değiştirme değeri $\varepsilon_{\mathrm{cu}}$ enine donatıda oluşan ilk kopma anındaki değere karşılık gelir. Sargılı betondaki maksimum basınç birim şekil değiştirmesi $\varepsilon_{\mathrm{cu}}$ Denklem 23'te verilmiştir:

$$
\varepsilon_{\mathrm{cu}}=0.004+\frac{1 \cdot 4 \cdot \rho_{\mathrm{s}} \cdot \mathrm{f}_{\mathrm{yw}} \cdot \varepsilon_{\mathrm{su}}}{\mathrm{f}_{\mathrm{cc}}^{\prime}}
$$

Burada $\rho_{\mathrm{s}}$ toplam enine donatının hacimsel oranını, $\varepsilon_{\mathrm{su}}$ enine donatı çeliğinde maksimum gerilme altındaki birim uzama şekil değiştirmesini göstermektedir.

\section{Sargılı beton için Saatçioğlu ve Ravzi modeli (Saatcioglu and Ravzi models for confined concrete)}

Saatçioğlu ve Ravzi (1992) çok sayıda dikdörtgen ve dairesel sargı donatılı betonarme numune üzerinde yaptıkları çalışmada sargı donatılı betonarme elemanlarda gerilme-şekil değiştirme $(\sigma-\varepsilon)$ modeli geliştirmişlerdir. Sargılı beton dayanımı, yanal sargı basınç etkisi dikkate alınarak Denklem 24'teki gibi yazılır.

$$
\mathrm{f}_{\mathrm{cc}}=\mathrm{k}_{3} \mathrm{f}_{\mathrm{c}}+\mathrm{k}_{1} \sigma_{2}
$$

Normal dayanımlı betonlar için genelde $k_{3}=0.85$ varsayılır. Saatçioğlu ve Ravzi (1992) $k_{1}$ için deney sonuçları ile iyi bir uyuşum gösteren Denklem 25'i önermektedir

$$
\mathrm{k}_{1}=\frac{6,7}{\left(\sigma_{2}\right)^{0,17}}
$$

Saatçioğlu ve Ravzi modeline göre dairesel kesitler için sargılı beton basınç dayanımı (Confined concrete strength for circular concrete sections according to Saatcioglu and Ravzi model)

Sık adımlarla yerleştirilmiş dairesel veya spiral sargı donatısının ve kolon boyuna donatısının mevcudiyeti ile de beton çekirdek etrafında sağlanacak yanal sargı basıncı düzgün yayılı olarak kabul edilebilir (Saatçioğlu ve Ravzi, 1992). Söz konusu basınç statikten Şekil 3’te görüldüğü gibi hesaplanabilir.

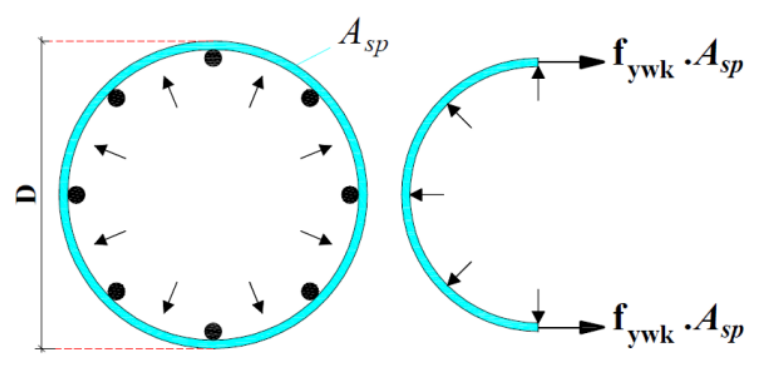

Şekil 3. Dairesel kolonlarda yanal sargı basıncı Figure 3. Lateral Pressure in Circular Columns 
Dairesel fretle sarılmış beton için çıkarılan $\sigma_{2}$ Denklem $26^{\prime}$ da verilmiştir. Bu denklemde $A_{o}, s$ ve $f_{y w k}$, sırasıyla fretin kesit alanı, aralığı ve akma dayanımıdır. D ise çekirdek çapıdır.

$$
\sigma_{2}=\frac{2 A_{o}}{D(s)} f_{y w k}
$$

Saatçioğlu ve Ravzi modeline göre kare kesitler için sargılı beton basınç dayanımı (Confined concrete strength for square concrete sections according to Saatcioglu and Ravzi model)

Aşağıdaki şekilde gösterildiği gibi, sargının kare olduğu durumlarda sargı donatısında eğilme deformasyonu hâkimdir. Bu nedenle köşelerde sargı etkisi belirginken bu etki, sargı donatısının açılık ortasında azalmaktadır. Bunun için, dikdörtgen sargı donatısının söz konusu olduğu durumlarda, betona uygulanan basınç düzgün yayılı değildir (Şekil 4).

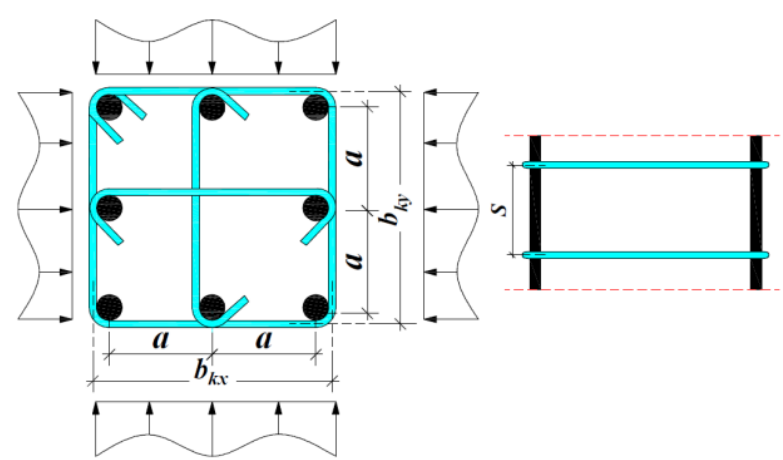

Şekil 4. Kare kolonlarda yanal sargı basincı

Figure 4. Lateral Pressure in Square Columns

Basınç dağılımındaki bu değişmeyi dikkate alabilmek için $\sigma_{2}$ yerine, eşdeğer düzgün yayılı basınç $\sigma_{2 \mathrm{e}}$, kullanılması önerilmektedir.

$$
\begin{aligned}
& \mathrm{f}_{\mathrm{cc}}=\mathrm{k}_{3} \mathrm{f}_{\mathrm{c}}+\mathrm{k}_{1} \sigma_{2 \mathrm{e}} \\
& \mathrm{k}_{1}=\frac{6,7}{\left(\sigma_{2 \mathrm{e}}\right)^{0,17}}
\end{aligned}
$$

Deneysel verilerden yararlanarak $\sigma_{2 \mathrm{e}}$ Denklem 29 ve 30'dan çıkartılmıştır (kare kesit $b_{k x}=b_{k y}$ ).

$$
\begin{aligned}
& \sigma_{2 \mathrm{e}}=\beta \sigma_{2} \\
& \sigma_{2}=\frac{\sum \mathrm{A}_{\mathrm{o}} \mathrm{f}_{\mathrm{ywk}}(\sin \alpha)}{\left(\mathrm{s} \times \mathrm{b}_{\mathrm{k}}\right)}
\end{aligned}
$$

Eşdeğer sargı basıncı, ortalama sargı basıncını $\beta$ ile tanımlanacak bir azaltma katsayısına bağlı olarak tanımlanmıştır.

$$
\beta=0,26 \sqrt{\left(\frac{b_{k}}{a}\right)\left(\frac{b_{k}}{s}\right)\left(\frac{1}{\sigma_{2}}\right)} \leq 1,0
$$

Denklem 31'deki "a" sargı donatısına mesnet oluşturan iki boyuna donatı merkezi arasındaki uzaklıktır. Boyuna donatının mesnet olabilmesi için, bu donatının etriye köşesinde yer alması veya çirozlarla tutturulmuş olması gerekir.

Saatçioğlu ve Ravzi modeline göre dikdörtgen kesit için sargılı beton basınç dayanımı (confined concrete strength for rectangular concrete sections according to Saatcioglu and Ravzi model)

Dairesel ve kare kesitler için belirtilen hesap yöntemi, dikdörtgen kesitli kolon elemanlarda da kullanılabilir. Dikdörtgen kesitli elemanlarda uzun kenara etkiyen sargı basıncı, kısa kenara etkiyen sargı basıncına göre beton dayanımı üzerinde daha çok etkili olmaktadır. Deneysel verilerin incelenmesi sonucunda dikdörtgen kesitli kolon elemanın uzun ve kısa kenarlarına etkiyen sargı basıncının kenar uzunlukları ile orantılı olduğu anlaşılmaktadır (Saatçioğlu ve Ravzi, 1992). 


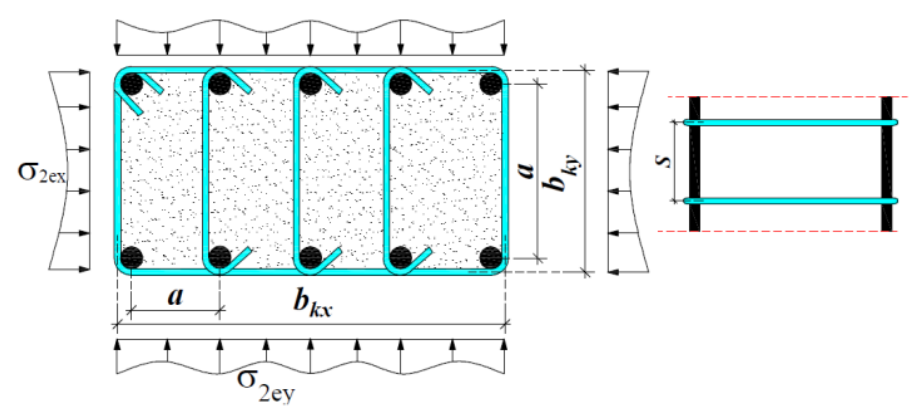

Şekil 5. Dikdörtgen kolonlarda yanal sargı basincı

Figure 5. Lateral Pressure Distribution in Rectangular Columns

Şekil 5'te görüleceği gibi $\sigma_{2 \mathrm{ex}}$ ve $\sigma_{2 \mathrm{ey}}$ kolon çekirdek alanına etkiyen ve sırasıyla $b_{\mathrm{kx}}$ ve $b_{\mathrm{ky}}$ kenarlarına dik olarak yayıldığı kabul edilen eşdeğer yanal sargı gerilmeleridir.

$$
\begin{aligned}
& \sigma_{2 \mathrm{e}}=\frac{\left(\sigma_{2 \mathrm{ex}} \mathrm{b}_{\mathrm{kx}}+\sigma_{2 \mathrm{ey}} \mathrm{b}_{\mathrm{ky}}\right)}{\left(\mathrm{b}_{\mathrm{kx}}+\mathrm{b}_{\mathrm{ky}}\right)} \\
& \sigma_{2 \mathrm{x}}=\frac{\sum \mathrm{A}_{\mathrm{ox}} \mathrm{f}_{\mathrm{ywk}} \sin \alpha}{\left(\mathrm{s} \times \mathrm{b}_{\mathrm{kx}}\right)}, \quad \sigma_{2 \mathrm{y}}=\frac{\sum \mathrm{A}_{\mathrm{oy}} \mathrm{f}_{\mathrm{ywk}} \sin \alpha}{\left(\mathrm{s} \times \mathrm{b}_{\mathrm{ky}}\right)}
\end{aligned}
$$

Dikdörtgen kesitlerde, " $\beta$ " azaltma katsayısı her iki yön için de ayrı ayrı hesaplanmalıdır:

$$
\begin{aligned}
& \beta_{\mathrm{x}}=0,26 \sqrt{\left(\frac{\mathrm{b}_{\mathrm{kx}}}{\mathrm{a}_{\mathrm{x}}}\right)\left(\frac{\mathrm{b}_{\mathrm{kx}}}{\mathrm{s}}\right)\left(\frac{1}{\sigma_{2 \mathrm{x}}}\right)} \leq 1,0, \quad \beta_{\mathrm{y}}=0,26 \sqrt{\left(\frac{\mathrm{b}_{\mathrm{ky}}}{\mathrm{a}_{\mathrm{y}}}\right)\left(\frac{\mathrm{b}_{\mathrm{ky}}}{\mathrm{s}}\right)\left(\frac{1}{\sigma_{2 \mathrm{y}}}\right)} \\
& \sigma_{2 \mathrm{ex}}=\beta_{\mathrm{x}} \sigma_{2 \mathrm{x}}, \quad \sigma_{2 \mathrm{ey}}=\beta_{\mathrm{y}} \sigma_{2 \mathrm{y}}
\end{aligned}
$$

Sargı donatılı betonun $\sigma-\varepsilon$ eğrisinin elde edilebilmesi için $f_{c c}$ 'nin hesaplanması yeterli değildir. fcc'ye karşı gelen birim kısalmanın $\left(\varepsilon_{\mathrm{coc}}\right)^{\prime}$ da tanımlanması gereklidir. Ayrıca eğrinin $\varepsilon_{\mathrm{coc}}$ 'dan sonraki bölümü de tanımlanmalıdır. Saatçioğlu ve Ravzi (1992) $\varepsilon_{\mathrm{coc}}$ için Denklem 36 ve 37'yi önermişlerdir $\left(\varepsilon_{\mathrm{co}}=0,002\right)$.

$$
\begin{aligned}
& \varepsilon_{\mathrm{coc}}=\varepsilon_{\mathrm{co}}[1+5 \lambda] \\
& \lambda=\frac{\mathrm{k}_{1} \sigma_{2 \mathrm{e}}}{\mathrm{k}_{3} \mathrm{f}_{\mathrm{c}}}
\end{aligned}
$$

$0.85 \mathrm{f}_{\mathrm{cc}}{ }^{\prime}$ ye karşı gelen birim kısalma için Denklem 38 ve 39 tanımlanmaktadır.

$$
\begin{aligned}
& \varepsilon_{\mathrm{c} 85}=260 \rho \varepsilon_{\mathrm{coc}}+\varepsilon_{\mathrm{u} 85} \\
& \rho=\frac{\sum \mathrm{A}_{\mathrm{oxy}} \sin \alpha}{\mathrm{s}\left(\mathrm{b}_{\mathrm{kx}}+\mathrm{b}_{\mathrm{ky}}\right)}
\end{aligned}
$$

Sargılı beton gerilme ilişkisi, betonun en büyük gerilme değerine kadar bir doğru ile ifade edilmiştir. Sargılı beton dayanımının \%20'sinin sonrası kalıcı dayanım seviyesi olarak kabul edilmiştir. Saatçioğlu ve Razvi (1992) beton modeli, yanal sargı basıncının sıfır veya ihmal edilebilir bir değerde olması durumunda Hognestad (1951) tarafından önerilen sargısız beton modeli haline gelmektedir (Saatçioğlu ve Ravzi, 1992).

Eğrinin birinci bölümü: $\sigma_{\mathrm{c}}=\mathrm{f}_{\mathrm{cc}}\left[\left(\frac{2 \varepsilon_{\mathrm{c}}}{\varepsilon_{\mathrm{coc}}}\right)-\left(\frac{\varepsilon_{\mathrm{c}}}{\varepsilon_{\mathrm{coc}}}\right)^{2}\right]^{\frac{1}{1+2 \lambda}} \leq \mathrm{f}_{\mathrm{cc}}$

Eğrinin ikinci bölümü: $\sigma_{\mathrm{c}}=\mathrm{f}_{\mathrm{cc}}+\left(\frac{\mathrm{f}_{\mathrm{cc}}-\mathrm{f}_{\mathrm{c} 85}}{\varepsilon_{\mathrm{coc}}-\varepsilon_{\mathrm{c} 85}}\right)\left(\varepsilon_{\mathrm{c}}-\varepsilon_{\mathrm{coc}}\right)$

\section{MATERYAL ve METOT (MATERIALS and METHODS)}

Bu çalışmada; ilk olarak doğrusal elastik olmayan davranışın daha iyi anlaşılabilmesi için gerilmeşekil değiştirme bağıntıları, Mander ve diğ. (1988a), Saatçioğlu ve Razvi (1992) tarafından sargılı betonarme elemanlar için önerilmiş olan eksenel yük altındaki davranış modelleri hakkında bilgi verilmiştir. Mander ve diğ. (1988a), Saatçioğlu ve Razvi (1992) modelleri kullanılarak sargılı ve sargısız beton davranışı dikkate alınarak kolon modellerinin sargılı beton basınç dayanımları araştırılmıştır. Sargılı kolon modellerinin gerilme- birim şekil değiştirme $(\sigma-\varepsilon)$ eğrileri elde edilmiştir. 
$\mathrm{Bu}$ çalışmada, betonarme kolon kesitlerine ait tasarım parametrelerinin, kesit davranışına etkisini incelenmek amacıyla değişik geometri ve parametrelere sahip toplam 33 adet betonarme kolon modeli tasarlanmıştır. Betonarme kolon modellerinin tasarımında TBDY, (2018)'de verilen hükümler dikkate alınmıştır. Değişik geometrilerde tasarlanan her betonarme kolon modeli için üç farklı sargı donatı çapı, her sargı donatı çapı için üç farklı sargı donatı aralığı olmak üzere toplam 99 adet betonarme kolon kesit modellerinin sargılı beton basınç dayanımları araştırılmıştır. Tasarlanan betonarme kolon modellerinin üç farklı malzeme modelinden oluştuğu düşünülmüştür. Farklı malzeme modeli olarak; sargısız beton modeli için kabuk betonu, sargılı beton modeli için çekirdek betonu ve donatı çeliği olarak S420 için verilen değerler kullanılmıştır (Çizelge 1). Tasarlanan betonarme kolon modellerine ait kesitlerin geometrileri, donatı yerleşim planı görünüşü Şekil 6'da verilmiştir. Şekil 6'da verilen betonarme kolon modellerinde boyuna donatı oranı, sargı donatısı çapı ve aralığının betonarme kesitlerin davranışına etkisi incelenmiştir. Farklı kesitler için tasarlanan boyuna donatı oranı, sargı donatı çapı ve sargı donatı aralığına sahip kesitlerin detayları aşağıda verilmiştir. Çizelge 2'de verilen kesitlerin her biri için farklı sargı donatı çapı ve sarg1 donatı aralığı için Mander ve diğ. (1988a), Saatçioğlu ve Razvi (1992) modelleri kullanılarak kesitlerin sargılı beton basınç dayanımları hesaplanmıştır.

Çizelge 1. Malzeme modellerinde kullanılan parametreler

Table 1. Material parameters used in the model

\begin{tabular}{|c|lc|}
\hline Malzeme & \multicolumn{1}{|c|}{ Parametre } & Değer \\
\hline \multirow{2}{*}{ Beton Sınıfı: } & Sargısız betonun maksimum gerilmeye ulaştı̆̆ birim şekil-değiştirme değeri $\left(\varepsilon_{\mathrm{co}}\right)$ & 0.002 \\
C30 & Sargısız betonun nihai birim şekil-değiştirmesi $\left(\varepsilon_{\mathrm{cu}}\right)$ & 0.0035 \\
& Karakteristik beton basınç dayanımı $\left(\mathrm{f}_{\mathrm{ck}}\right)$ & $30 \mathrm{MPa}$ \\
\hline & Donatı çeliğinin akma birim şekil değiştirmesi $\left(\varepsilon_{\mathrm{sy}}\right)$ & 0.0021 \\
Donatı Çeliği: & Donatı çeliğinin pekleşme birim şekil değiştirmesi $\left(\varepsilon_{\mathrm{sp}}\right)$ & 0.008 \\
S420 & Donatı çeliğinin kopma birim şekil değiştirmesi $\left(\varepsilon_{\mathrm{su}}\right)$ & 0.10 \\
& Donatı çeliğinin karakteristik akma dayanımı $\left(\mathrm{f}_{\mathrm{yk}}\right)$ & $420 \mathrm{MPa}$ \\
& Donatı çeliğinin karakteristik kopma dayanımı $\left(\mathrm{f}_{\mathrm{su}}\right)$ & $550 \mathrm{MPa}$ \\
\hline
\end{tabular}
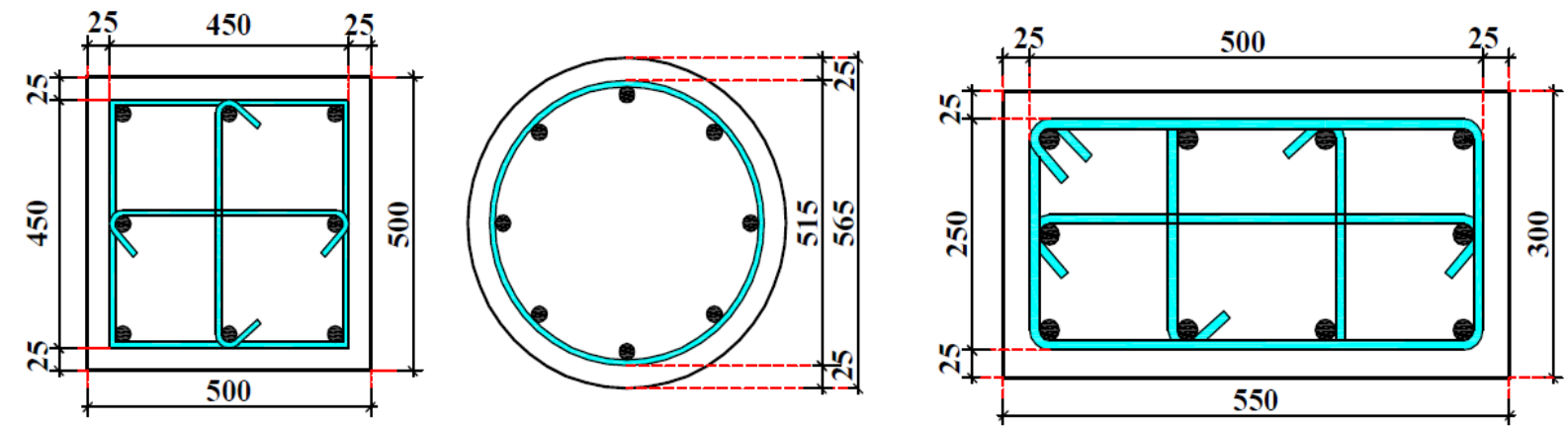

Şekil 6. Tasarlanan kolon modellerinin kesit detayları Figure 6. Section details of designed column models

Tasarlanan farklı geometri ve parametrelere sahip betonarme kolonların kesit bilgileri ve detayları Çizelge 2' de verilmektedir. Farklı parametrelere göre toplam 99 adet kolon modeli tasarlanmıştır. Çizelge 2' de verilen betonarme kolonların her boyuna donatı oranı için üç farklı sargı donatı çapı ve üç farklı sargı donatı aralığına göre sargılı beton basınç dayanımları araştırılmıştır. Sargılı beton basınç dayanımları hesaplanarak kesitlerin gerilme-şekil değiştirme ilişkileri elde edilmiştir. Farklı parametrelere göre elde edilen gerilme-şekil değiştirme ilişkileri farklı kolon modelleri için karşılaştırarak yorumlanmıştır. TBDY, (2018)'e göre kolonlarda boyuna donatı alanı, brüt kesitin \%1'inden az, \%4'ünden daha büyük olmayacak şekilde tasarlanmıştır. Kolon modellerinde boyuna donatı olarak $\Phi 20$ 'den $\Phi 40$ 'a kadar farklı donatılar kullanılmıştır. 
Çizelge 2. Tasarlanan betonarme kolon modellerine ait parametreler

Table 2. Parameters of reinforced concrete column models

\begin{tabular}{|c|c|c|c|c|c|c|c|c|c|c|}
\hline \multicolumn{3}{|c|}{ Kare kolon } & \multicolumn{2}{|c|}{ Dairesel kolon } & \multicolumn{3}{|c|}{ Dikdörtgen kolon } & \multirow{2}{*}{$\begin{array}{c}\text { Boyuna donatı } \\
\text { Çap } \\
\end{array}$} & \multicolumn{2}{|c|}{ Sarg1 donatıs1 } \\
\hline No & $\mathrm{b}$ & $\mathrm{h}$ & No & $\mathrm{D}$ & No & $\mathrm{b}$ & $\mathrm{h}$ & & Çap & Aralık $(\mathrm{mm})$ \\
\hline S1 & & & CR1 & & REC1 & & & $\Phi 20$ & $\Phi 8, \Phi 10, \Phi 12$ & $50,75,100$ \\
\hline S2 & & & CR2 & & REC2 & & & $\Phi 22$ & Ф8, Ф10, Ф12 & $50,75,100$ \\
\hline S3 & & & CR3 & & REC3 & & & $\Phi 24$ & $\Phi 8, \Phi 10, \Phi 12$ & $50,75,100$ \\
\hline S4 & & & CR4 & & REC4 & & & $\Phi 26$ & Ф8, Ф10, Ф12 & $50,75,100$ \\
\hline S5 & & & CR5 & & REC5 & & & $\Phi 28$ & $\Phi 8, \Phi 10, \Phi 12$ & $50,75,100$ \\
\hline S6 & 500 & 500 & CR6 & 565 & REC6 & 300 & 550 & Ф30 & $\Phi 8, \Phi 10, \Phi 12$ & $50,75,100$ \\
\hline S7 & & & CR7 & & REC7 & & & Ф32 & $\Phi 8, \Phi 10, \Phi 12$ & $50,75,100$ \\
\hline S8 & & & CR8 & & REC8 & & & Ф34 & $\Phi 8, \Phi 10, \Phi 12$ & $50,75,100$ \\
\hline S9 & & & CR9 & & REC9 & & & Ф36 & $\Phi 8, \Phi 10, \Phi 12$ & $50,75,100$ \\
\hline S10 & & & CR10 & & REC10 & & & Ф38 & $\Phi 8, \Phi 10, \Phi 12$ & $50,75,100$ \\
\hline S11 & & & CR11 & & REC11 & & & $\Phi 40$ & $\Phi 8, \Phi 10, \Phi 12$ & $50,75,100$ \\
\hline
\end{tabular}

\section{ANALİTIK ÇALIŞMA (ANALYTICAL STUDY)}

Tasarlanan yapısal betonarme kolonların yanal sargı basıncına etkiyen parametreler sirasiyla boyuna donatı oranı, sargı donatısı çapı, sargı donatısı aralığı ele alınarak sargılı beton basınç dayanımı hesaplanmıştır. Boyuna donatı oranının, sargı donatı çapının ve sarg1 donatı aralığının tasarlanan betonarme kolonların davranışı üzerindeki etkisi Mander ve diğ. (1988a), Saatçioğlu ve Razvi (1992) modellerine göre sargılı beton basınç dayanımları hesaplanarak araştırılmıştır. Farklı parametrelere göre elde edilen gerilme-şekil değiştirme ilişkileri farklı betonarme kolon modelleri için karşılaştırılarak yorumlanmıştır. Saatçioğlu ve Razvi (1992) modellerine göre kare en-kesitli kolon modelleri için yapılan hesap sonuçları Çizelgeler halinde özetlenmiştir. Mander ve diğ. (1988a) modeline göre tasarlanan kare en-kesitli kolon modellerinde hesaplanan değerler incelendiğinde aşağıdaki sonuçlar elde edilmiştir (Çizelge 3).

Çizelge 3. Mander modeline göre kare en-kesitli kolon modellerinin hesap sonuçları Table 3. Calculation results of square cross-sectional column models according to Mander model

\begin{tabular}{|c|cccccccccc|}
\hline No & Boyuna donatı & Sargi donatisi & $\mathrm{A}_{\mathrm{e}}\left(\mathrm{mm}^{2}\right)$ & $k_{e}$ & $\rho_{\mathrm{s}}$ & $\mathrm{f}_{\mathrm{l}}(\mathrm{Mpa})$ & $\mathrm{f}_{\mathrm{l}}^{\prime}(\mathrm{Mpa})$ & $\mathrm{f}_{\mathrm{cc}}^{\prime}(\mathrm{Mpa})$ & $\varepsilon_{\mathrm{cc}}$ & $\varepsilon_{\mathrm{cu}}$ \\
\hline \multirow{6}{*}{$\mathrm{S} 1$} & & $\Phi 8 / 50$ & 134940.88 & 0.70 & 0.0136 & 2.87 & 2.01 & 37.27 & 0.0066 & 0.0212 \\
& & $\Phi 8 / 75$ & 127046.73 & 0.659 & 0.009 & 1.91 & 1.26 & 33.32 & 0.0051 & 0.0168 \\
& & $\Phi 8 / 100$ & 119390.48 & 0.619 & 0.0068 & 1.43 & 0.890 & 31.18 & 0.0042 & 0.0143 \\
& & $\Phi 10 / 50$ & 134820.86 & 0.705 & 0.0214 & 4.5 & 3.17 & 42.72 & 0.0088 & 0.0276 \\
& & $\Phi 10 / 75$ & 126915.23 & 0.664 & 0.0142 & 3.0 & 1.99 & 37.20 & 0.0066 & 0.0221 \\
& & $\Phi 10 / 100$ & 119248.44 & 0.624 & 0.0107 & 2.25 & 1.40 & 34.12 & 0.0054 & 0.0188 \\
& & $\Phi 12 / 50$ & 134698.89 & 0.711 & 0.0310 & 6.51 & 4.63 & 48.57 & 0.0110 & 0.0340 \\
& & $\Phi 12 / 75$ & 126781.85 & 0.669 & 0.0206 & 4.34 & 2.90 & 41.53 & 0.0083 & 0.0274 \\
& & $\Phi 12 / 100$ & 119104.57 & 0.629 & 0.0154 & 3.25 & 2.05 & 37.48 & 0.0067 & 0.0234 \\
\hline
\end{tabular}

Mander ve diğg. (1988a) modeline göre kare en-kesitli kolon modellerinden hesaplanan sargılı beton için gerilme-şekil değiştirme bağıntıları tanımlanmıştır. Sargılı betonda basınç gerilmesi $\mathrm{f}_{\mathrm{cc}}^{\prime}$, basınç birim şekil değiştirmesi $\varepsilon_{\text {cc }}$ 'nin fonksiyonu olarak elde edilen $\sigma-\varepsilon$ ilişkileri Şekil 7'de özetlenmiştir. Farklı sargı donatı aralıkları için Şekil $7^{\prime}$ de verilen $\sigma-\varepsilon$ eğrisi $8 \mathrm{~mm}, 10 \mathrm{~mm}$ ve $12 \mathrm{~mm}$ sargı donatı çapına göre hazırlanmıştır. Tasarlanan betonarme kolon modellerinde boyuna donatı oranı, sarg1 donatı çapı ve sarg1 donatı aralığının değişiminin, sargılı beton dayanımına etkisi Mander ve diğ. (1988a) beton modeline göre hesaplanarak karşılaştırılmıştır. 

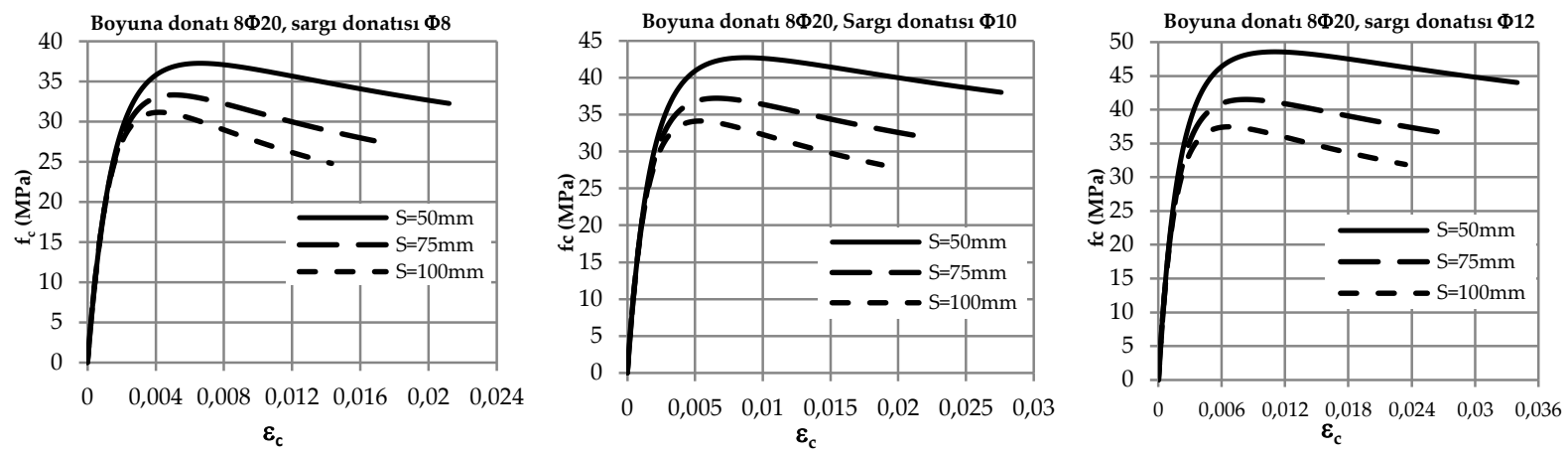

Şekil 7. Mander modeline göre kare en-kesitli kolonların gerilme-şekil değiştirme grafikleri Figure 7. Stress-strain curves of square cross-section column models according to Mander model

Tasarlanan kare en-kesitli betonarme kolon modellerinin Saatçioğlu ve Ravzi (1992) modeline göre hesap sonuçları Çizelge 4 'te verilmiştir.

Çizelge 4. Saatçioğlu ve Ravzi modeline göre kare en-kesitli kolon modellerinin hesap sonuçları Table 4. Calculation results of square cross section column models according to Saatcioglu and Ravzi model

\begin{tabular}{|c|cccccccccc|}
\hline No & Boyuna donatı & Sargl donatist & $\rho_{s}$ & $\sigma_{2}(\mathrm{MPa})$ & $\sigma_{22}(\mathrm{MPa})$ & $k_{1}$ & $f_{c c}(\mathrm{MPa})$ & $\varepsilon_{c c c}$ & $\varepsilon_{c 85}$ & $\varepsilon_{c 20}$ \\
\hline \multirow{5}{*}{$\mathrm{S} 1$} & $\Phi 8 / 50$ & 0.0068 & 2.865 & 1.912 & 6.00 & 36.97 & 0.0065 & 0.0153 & 0.0536 \\
& & $\Phi 8 / 75$ & 0.0045 & 1.910 & 1.274 & 6.430 & 33.69 & 0.0052 & 0.0130 & 0.0470 \\
& & $\Phi 8 / 100$ & 0.0034 & 1.433 & 0.956 & 6.751 & 31.95 & 0.0045 & 0.0118 & 0.0435 \\
& & $\Phi 10 / 50$ & 0.0107 & 4.498 & 2.396 & 5.775 & 39.33 & 0.0074 & 0.0244 & 0.0983 \\
& & $\Phi 10 / 75$ & 0.0071 & 2.998 & 1.597 & 6.187 & 35.38 & 0.0058 & 0.0201 & 0.0820 \\
& & $\Phi 10 / 100$ & 0.0053 & 2.249 & 1.198 & 6.497 & 33.28 & 0.0050 & 0.0178 & 0.0734 \\
& & $\Phi 12 / 50$ & 0.0154 & 6.506 & 2.883 & 5.596 & 41.63 & 0.0083 & 0.0373 & 0.1630 \\
& & $\Phi 12 / 75$ & 0.0103 & 4.338 & 1.922 & 5.995 & 37.02 & 0.0065 & 0.0300 & 0.1320 \\
& & $\Phi 12 / 100$ & 0.0077 & 3.253 & 1.441 & 6.296 & 34.57 & 0.0055 & 0.0262 & 0.1156 \\
\hline
\end{tabular}

Saatçioğlu ve Ravzi (1992) modeline göre kare en-kesitli kolon modellerinden hesaplanan sargılı beton için gerilme-şekil değiştirme bağıntıları tanımlanmıştır (Şekil 8). Farklı sargı donatı aralıkları için Şekil 8 'de verilen $\sigma-\varepsilon$ eğrileri $8 \mathrm{~mm}, 10 \mathrm{~mm}$ ve $12 \mathrm{~mm}$ sargı donatı çapına göre hazırlanmıştır.
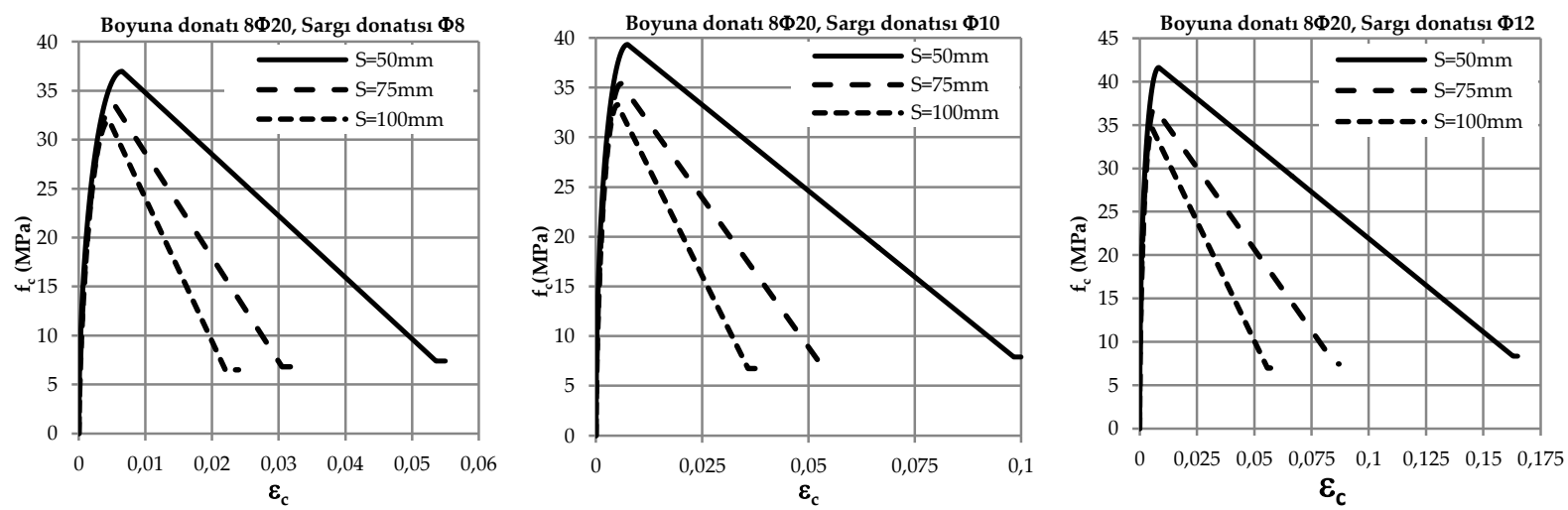

Şekil 8. Saatçioğlu ve Ravzi modeline göre kare en-kesitli kolonların gerilme-şekil değiştirme grafikleri Figure 8. Stress-strain curves of square cross-section column models according to Saatcioglu and Ravzi model

Tasarlanan dairesel en-kesitli betonarme kolon elemanlarının yanal sarg1 basincina etkiyen parametreler sırasıyla boyuna donatı oranı, sargı donatısının çapı ve sargı donatısı aralığı ele alınarak sargılı beton basınç dayanımları hesaplanmıştır (Çizelge 5). Yapılan hesaplar sonucunda farklı parametrelere göre gerilme şekil değiştirme eğrileri çizilmiştir. 
Çizelge 5. Mander modeline göre dairesel en-kesitli kolon modellerinin hesap sonuçları Table 5. Calculation results of circular cross-sectional column models according to Mander model

\begin{tabular}{|c|c|c|c|c|c|c|c|c|c|c|}
\hline No & $\begin{array}{c}\text { Boyuna } \\
\text { donatı }\end{array}$ & $\begin{array}{c}\text { Sargl } \\
\text { donatısı }\end{array}$ & $A_{e}\left(m m^{2}\right)$ & $\mathrm{k}_{\mathrm{e}}\left(\mathrm{mm}^{2}\right)$ & $\rho_{\mathrm{s}}\left(\mathrm{mm}^{2}\right)$ & $\mathrm{f}_{\mathrm{l}}(M p a)$ & $\mathrm{f}_{\mathrm{l}}^{\prime}(\mathrm{Mpa})$ & $\mathrm{f}_{\mathrm{cc}}^{\prime}(M p a)$ & $\varepsilon_{c c}$ & $\varepsilon_{c u}$ \\
\hline \multirow{9}{*}{ CR1 } & \multirow{9}{*}{$8 \Phi 20$} & $\Phi 8 / 50$ & 185507.90 & 0.968 & 0.0079 & 1.66 & 1.61 & 35.24 & 0.0085 & 0.0145 \\
\hline & & $\Phi 8 / 75$ & 176088.03 & 0.943 & 0.0052 & 1.11 & 1.05 & 32.12 & 0.0046 & 0.0117 \\
\hline & & $\Phi 8 / 100$ & 166913.60 & 0.918 & 0.0039 & 0.832 & 0.765 & 30.45 & 0.0039 & 0.0101 \\
\hline & & $\Phi 10 / 50$ & 184745.28 & 0.970 & 0.0124 & 2.61 & 2.53 & 39.83 & 0.0076 & 0.0187 \\
\hline & & $\Phi 10 / 75$ & 175345.04 & 0.945 & 0.0083 & 1.74 & 1.64 & 35.42 & 0.0059 & 0.0150 \\
\hline & & $\Phi 10 / 100$ & 166190.25 & 0.920 & 0.0062 & 1.30 & 1.20 & 33.00 & 0.0049 & 0.0128 \\
\hline & & $\Phi 12 / 50$ & 183984.23 & 0.972 & 0.0179 & 3.77 & 3.67 & 44.82 & 0.0095 & 0.0228 \\
\hline & & $\Phi 12 / 75$ & 174603.63 & 0.946 & 0.0120 & 2.52 & 2.38 & 39.12 & 0.0073 & 0.0184 \\
\hline & & $\Phi 12 / 100$ & 165468.47 & 0.921 & 0.0090 & 1.88 & 1.74 & 35.91 & 0.0060 & 0.0157 \\
\hline
\end{tabular}

Mander ve diğ. (1988a) modeline göre dairesel en-kesitli kolon modelleri için hesaplanan sargılı beton gerilme-şekil değiştirme bağıntıları tanımlanmıştır. Sargılı betonda basınç gerilmesi $\mathrm{f}_{\mathrm{cc}}$, basınç birim şekil değiştirmesi $\varepsilon_{\mathrm{cc}}$ 'nin fonksiyonu olarak elde edilen $\sigma-\varepsilon$ ilişkileri Şekil 9' da özetlenmiştir. Farklı sargı donatı aralıkları için Şekil 9'da verilen $\sigma-\varepsilon$ eğrileri $8 \mathrm{~mm}, 10 \mathrm{~mm}$ ve $12 \mathrm{~mm}$ sargı donatı çapına göre hazırlanmıştır.
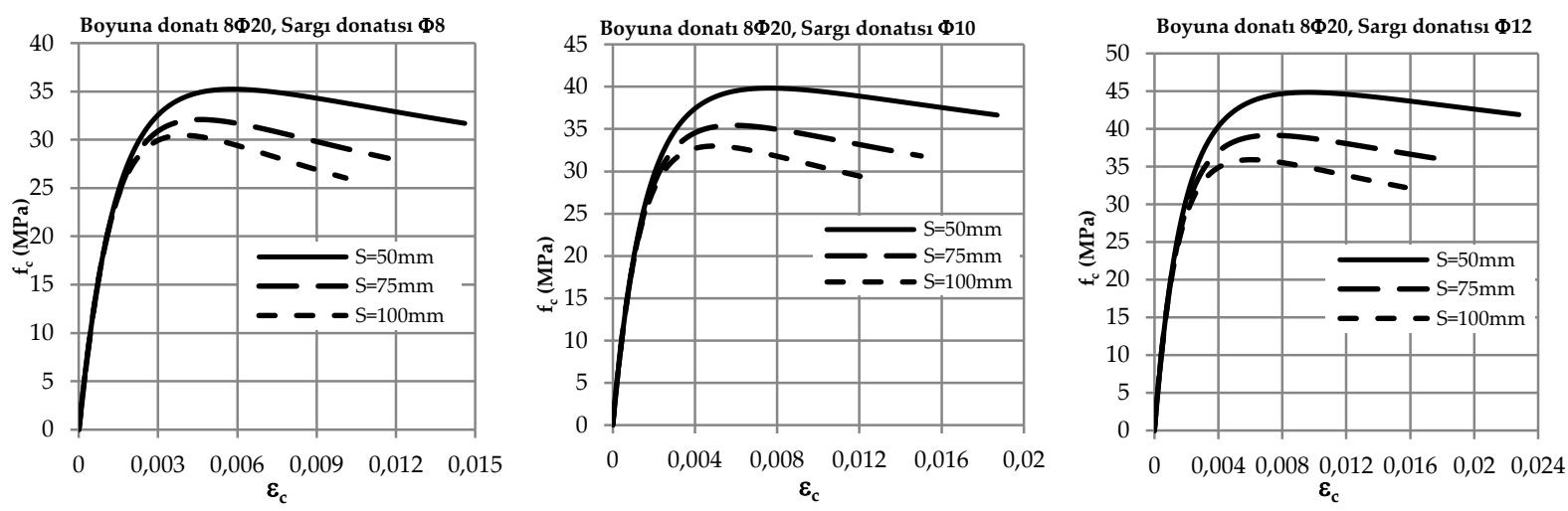

Şekil 9. Mander modeline göre dairesel en-kesitli kolonların gerilme-şekil değiştirme grafikleri Figure 9. Stress-strain curves of circular cross-section column models according to Mander model

Tasarlanan dairesel en-kesitli betonarme kolon modellerinin Saatçioğlu ve Ravzi (1992) modeline göre hesap sonuçları Çizelge 6'da verilmiştir.

Çizelge 6. Saatçioğlu ve Ravzi modeline göre göre dairesel en-kesitli kolon modellerinin hesap sonuçları Table 6. Calculation results of circular cross-sectional column models according to Saatcioglu and Ravzi model

\begin{tabular}{|c|ccccccccc|}
\hline No & Boyuna donati & Sargi donatısi & $\rho_{s}$ & $\sigma_{2}(\mathrm{MPa})$ & $K_{1}$ & $f_{c c}(\mathrm{MPa})$ & $\varepsilon_{c o c}$ & $\varepsilon_{c 85}$ & $\varepsilon_{c 20}$ \\
\hline \multirow{6}{*}{ CR1 } & & $\Phi 8 / 50$ & 0.0079 & 1.665 & 6.143 & 35.73 & 0.0060 & 0.0162 & 0.0603 \\
& & $\Phi 8 / 75$ & 0.0052 & 1.110 & 6.581 & 32.80 & 0.0048 & 0.0104 & 0.0348 \\
& & $\Phi 8 / 100$ & 0.0039 & 0.832 & 6.911 & 31.25 & 0.0042 & 0.0081 & 0.0252 \\
& & $\Phi 10 / 50$ & 0.0124 & 2.612 & 5.690 & 40.36 & 0.0078 & 0.0291 & 0.1214 \\
& & $\Phi 10 / 75$ & 0.0082 & 1.741 & 6.096 & 36.12 & 0.0061 & 0.0170 & 0.0644 \\
& & $\Phi 10 / 10$ & 0.0062 & 1.306 & 6.402 & 33.86 & 0.0052 & 0.0123 & 0.0429 \\
& & $\Phi 12 / 50$ & 0.0179 & 3.777 & 5.345 & 45.69 & 0.0099 & 0.0501 & 0.2246 \\
& & $\Phi 12 / 75$ & 0.0120 & 2.518 & 5.726 & 39.92 & 0.0076 & 0.0276 & 0.1143 \\
& & $\Phi 12 / 100$ & 0.0090 & 1.888 & 6.013 & 36.85 & 0.0064 & 0.0189 & 0.0727 \\
\hline
\end{tabular}



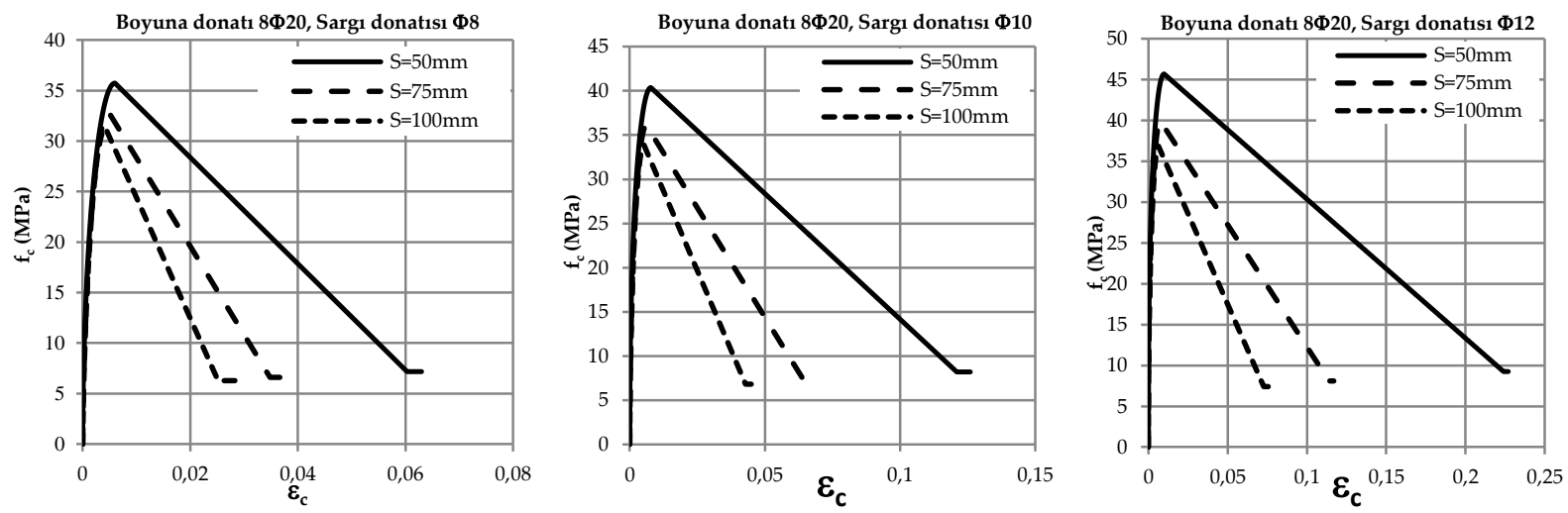

Şekil 10. Saatçioğlu ve Ravzi modeline göre dairesel en-kesitli kolonların gerilme-şekil değiştirme grafikleri

Figure 10. Stress-strain curves of square cross-section column models according to Saatcioglu and Ravzi model

Mander ve diğ. (1988a) modeline göre tasarlanan dikdörtgen en-kesitli kolon modellerinde hesaplanan değerler incelendiğinde aşağıdaki sonuçlar elde edilmiştir (Çizelge 7).

Çizelge 7. Mander modeline göre dikdörtgen en-kesitli kolon modellerinin hesap sonuçları Table 7. Calculation results of rectangular cross-sectional column models according to Mander model

\begin{tabular}{|c|ccccccccccc|}
\hline \multirow{3}{*}{ No } & Sargi donatisi & $\rho_{s}$ & $\begin{array}{c}f_{l x} \\
(\mathrm{MPa})\end{array}$ & $\begin{array}{c}f_{l y} \\
(\mathrm{MPa})\end{array}$ & $\begin{array}{c}f_{l} \\
(\mathrm{MPa})\end{array}$ & $\begin{array}{c}f_{l x}^{\prime} \\
(\mathrm{MPa})\end{array}$ & $\begin{array}{c}f_{l y}^{\prime} \\
(\mathrm{MPa})\end{array}$ & $\begin{array}{c}f_{l}^{\prime} \\
(\mathrm{MPa})\end{array}$ & $\begin{array}{c}f_{c c} \\
(\mathrm{MPa})\end{array}$ & $\varepsilon_{c c}$ & $\varepsilon_{c u}$ \\
\hline \multirow{6}{*}{ REC1 } & $\Phi 8 / 50$ & 0.0207 & 3.43 & 5.23 & 4.33 & 2.48 & 3.78 & 3.13 & 42.55 & 0.0087 & 0.0268 \\
& $\Phi 8 / 75$ & 0.0138 & 2.29 & 3.49 & 2.89 & 1.52 & 2.32 & 1.92 & 36.83 & 0.0064 & 0.0216 \\
& $\Phi 8 / 100$ & 0.0103 & 1.72 & 2.62 & 2.17 & 1.04 & 1.59 & 1.32 & 34.63 & 0.0052 & 0.0184 \\
& $\Phi 10 / 50$ & 0.0325 & 5.39 & 8.25 & 6.82 & 3.93 & 6.02 & 4.97 & 49.84 & 0.0115 & 0.0346 \\
& $\Phi 10 / 75$ & 0.0216 & 3.59 & 5.50 & 4.54 & 2.41 & 3.68 & 3.04 & 42.16 & 0.0085 & 0.0281 \\
& $\Phi 10 / 100$ & 0.0162 & 2.69 & 4.12 & 3.41 & 1.65 & 2.53 & 2.09 & 37.68 & 0.0068 & 0.0243 \\
& $\Phi 12 / 50$ & 0.0471 & 7.79 & 11.98 & 9.88 & 5.74 & 8.82 & 7.28 & 57.34 & 0.0145 & 0.0426 \\
& $\Phi 12 / 75$ & 0.0314 & 5.19 & 7.98 & 6.59 & 3.51 & 5.40 & 4.45 & 47.91 & 0.0108 & 0.0348 \\
& $\Phi 12 / 100$ & 0.0235 & 3.89 & 5.99 & 4.94 & 2.41 & 3.70 & 3.05 & 42.19 & 0.0085 & 0.0302 \\
\hline
\end{tabular}

Mander ve diğ. (1988a) modeline göre dikdörtgen en-kesitli kolon modellerinden hesaplanan sargilı beton için gerilme-şekil değiştirme bağıntıları tanımlanmıştır. Sargılı betonda basınç gerilmesi $f_{c c}^{\prime}$, basınç birim şekil değiştirmesi $\varepsilon_{\mathrm{cc}}$ 'nin fonksiyonu olarak elde edilen $\sigma-\varepsilon$ ilişkileri Şekil 11'de özetlenmiştir. Farklı sargı donatı aralıkları için Şekil 11'de verilen $\sigma-\varepsilon$ eğrileri $8 \mathrm{~mm}$, $10 \mathrm{~mm}$ ve $12 \mathrm{~mm}$ sargı donatı çapına göre hazırlanmıştır.
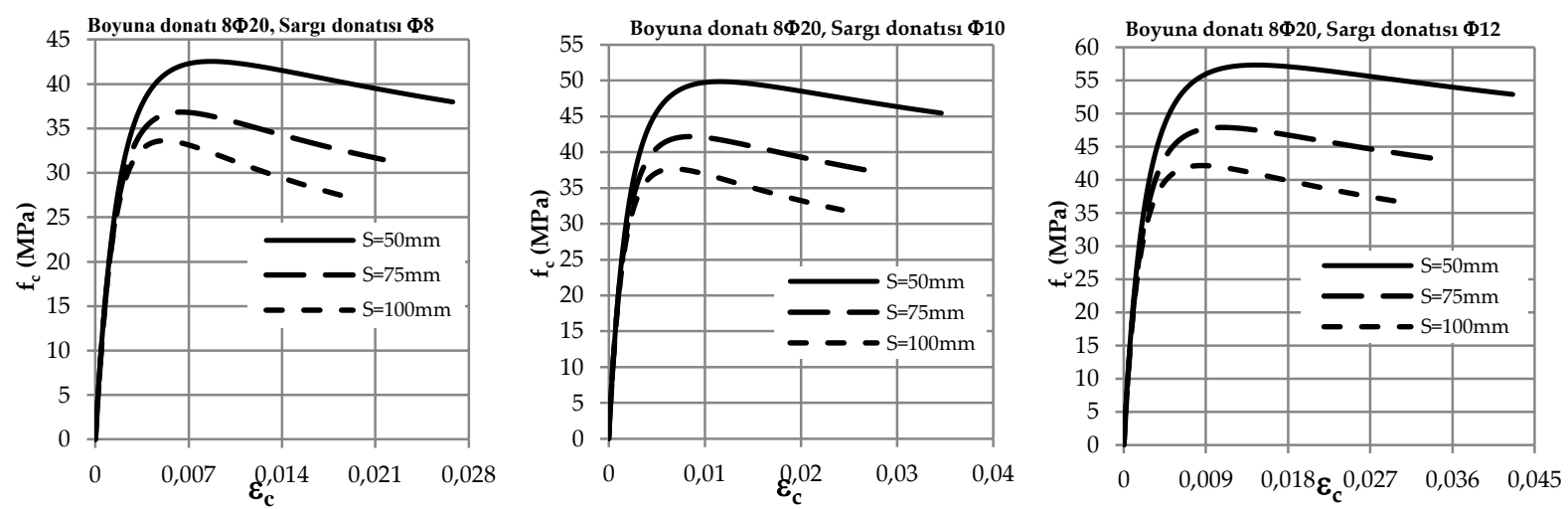

Şekil 11. Mander modeline göre dikdörtgen en-kesitli kolonların gerilme-şekil değiştirme grafikleri Figure 11. Stress-strain curves of rectangular cross-section column models according to Mander model 
Tasarlanan dairesel en-kesitli betonarme kolon modellerinin Saatçioğlu ve Ravzi (1992) modeline göre hesap sonuçları Çizelge 8'de verilmiştir.

Çizelge 8. Saatçioğlu ve Ravzi modeline göre dikdörtgen en-kesitli kolon modellerinin hesap sonuçları Table 8. Calculation results of rectangular cross-sectional column models according to Saatcioglu and Ravzi model

\begin{tabular}{|c|ccccccccccccc|}
\hline \multirow{2}{*}{ No } & $\begin{array}{c}\text { Sargl } \\
\text { donatisl }\end{array}$ & $\rho_{s}$ & $\begin{array}{c}\sigma_{2 x} \\
(\mathrm{MPa})\end{array}$ & $\begin{array}{c}\sigma_{2 y} \\
(\mathrm{MPa})\end{array}$ & $\begin{array}{c}\sigma_{2 e x} \\
(\mathrm{MPa})\end{array}$ & $\begin{array}{c}\sigma_{2 e y} \\
(\mathrm{MPa})\end{array}$ & $\begin{array}{c}\sigma_{2 e} \\
(\mathrm{MPa})\end{array}$ & $K_{1}$ & $\begin{array}{c}f_{c c} \\
(\mathrm{MPa})\end{array}$ & $\varepsilon_{c o c}$ & $\varepsilon_{c 85}$ & $\varepsilon_{c 20}$ \\
\hline \multirow{6}{*}{ REC1 } & $\Phi 8 / 50$ & 0.0096 & 3.43 & 5.23 & 1.59 & 3.33 & 2.76 & 5.64 & 41.04 & 0.0081 & 0.0240 & 0.0928 \\
& $\Phi 8 / 75$ & 0.0064 & 2.29 & 3.49 & 1.06 & 2.22 & 1.84 & 6.04 & 36.60 & 0.0063 & 0.0144 & 0.0490 \\
& $\Phi 8 / 100$ & 0.0048 & 1.72 & 2.62 & 0.80 & 1.66 & 1.38 & 6.34 & 34.24 & 0.0054 & 0.0105 & 0.0328 \\
& $\Phi 10 / 50$ & 0.0150 & 5.39 & 8.25 & 2.00 & 4.18 & 3.46 & 5.42 & 44.28 & 0.0093 & 0.0404 & 0.1752 \\
& $\Phi 10 / 75$ & 0.0100 & 3.59 & 5.50 & 1.33 & 2.79 & 2.31 & 5.81 & 38.91 & 0.0072 & 0.0227 & 0.0899 \\
& $\Phi 10 / 100$ & 0.0075 & 2.69 & 4.12 & 1.00 & 2.09 & 1.73 & 6.10 & 36.06 & 0.0061 & 0.0158 & 0.0578 \\
& $\Phi 12 / 50$ & 0.0218 & 7.79 & 11.98 & 2.41 & 5.04 & 4.17 & 5.26 & 47.44 & 0.0106 & 0.0639 & 0.295 \\
& $\Phi 12 / 75$ & 0.0145 & 5.19 & 7.98 & 1.60 & 3.36 & 2.78 & 5.63 & 41.17 & 0.0081 & 0.0345 & 0.1492 \\
& $\Phi 12 / 100$ & 0.0109 & 3.89 & 5.99 & 1.20 & 2.52 & 2.09 & 5.91 & 37.84 & 0.0068 & 0.0232 & 0.0940 \\
\hline
\end{tabular}

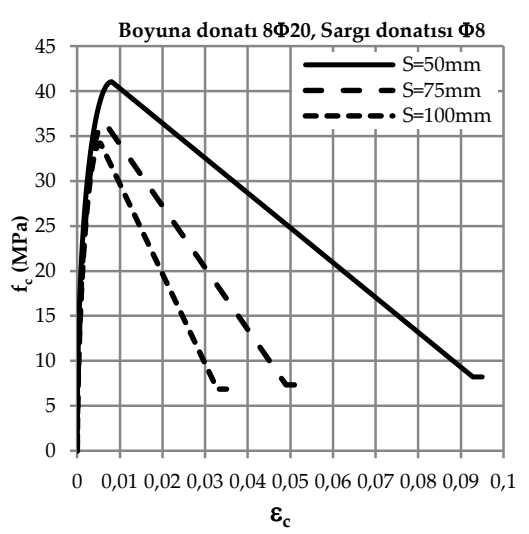

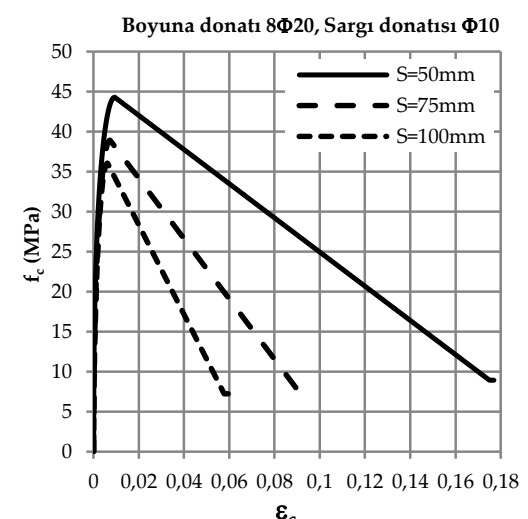

$\varepsilon_{\mathrm{c}}$

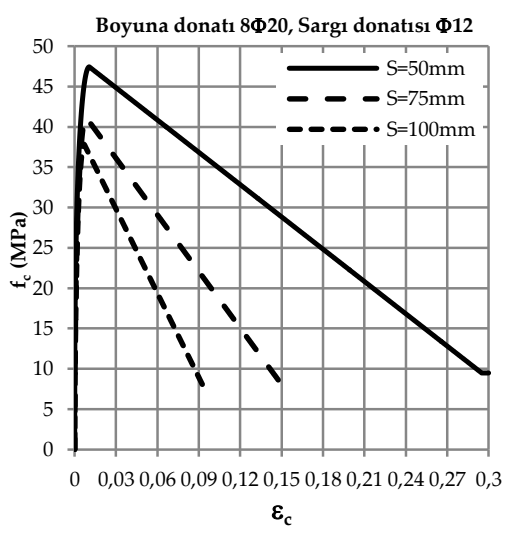

$\varepsilon_{\mathrm{c}}$

Şekil 12. Saatçioğlu ve Ravzi modeline göre dikdörtgen en-kesitli kolonların gerilme-şekil değiştirme grafikleri

Figure 12. Stress-strain curves of rectangular cross-section column models according to Saatcioglu and Ravzi model

Farklı boyuna donatı oranına sahip kare en-kesitli betonarme kolon kesitleri Mander ve diğ. (1988a), Saatçioğlu ve Razvi (1992) modelleri kullanılarak kesitlerin sargılı beton basınç dayanımları hesaplanmıştır. Çizelge 9 ve $10^{\prime}$ da kare en-kesitli betonarme kolon kesitlerinin farklı boyuna donatı oranı için sargılı beton basınç dayanımları sunulmuştur. 
Çizelge 9. Mander modeline göre kare en-kesitli kolon modellerinin hesap sonuçları Table 9. Calculation results of square cross-sectional column models according to Mander model

\begin{tabular}{|c|c|c|c|c|c|c|c|c|}
\hline No & Boyuna donatı & Sargı donatısı & $\rho_{s}$ & $\begin{array}{c}f_{l} \\
(\mathrm{MPa})\end{array}$ & $\begin{array}{c}f_{l}^{\prime} \\
(M P a)\end{array}$ & $\begin{array}{c}f_{c c}^{\prime} \\
(M P a)\end{array}$ & $\varepsilon_{c c}$ & $\varepsilon_{c u}$ \\
\hline S1 & $8 \Phi 20$ & & & 2.87 & 2.01 & 37.27 & 0.0066 & 0.0212 \\
\hline S2 & $8 \Phi 22$ & & & 2.86 & 2.03 & 37.39 & 0.0067 & 0.0212 \\
\hline S3 & $8 \Phi 24$ & & & 2.86 & 2.06 & 37.52 & 0.0067 & 0.0211 \\
\hline S4 & $8 \Phi 26$ & & & 2.86 & 2.08 & 37.65 & 0.0068 & 0.0210 \\
\hline S5 & $8 \Phi 28$ & & & 2.86 & 2.10 & 37.78 & 0.0068 & 0.0210 \\
\hline S6 & 8Ф30 & $\Phi 8 / 50$ & 0.0136 & 2.86 & 2.13 & 37.92 & 0.0069 & 0.0209 \\
\hline S7 & 8Ф32 & & & 2.86 & 2.16 & 38.05 & 0.0069 & 0.0209 \\
\hline S8 & 8Ф34 & & & 2.86 & 2.19 & 38.19 & 0.0070 & 0.208 \\
\hline S9 & 8Ф36 & & & 2.86 & 2.22 & 38.33 & 0.0070 & 0.0207 \\
\hline S10 & $8 Ф 38$ & & & 2.86 & 2.25 & 38.47 & 0.0071 & 0.0207 \\
\hline S11 & $8 \Phi 40$ & & & 2.86 & 2.28 & 38.62 & 0.0071 & 0.0206 \\
\hline
\end{tabular}

Çizelge 10. Saatçioğlu ve Ravzi modeline göre kare en-kesitli kolon modellerinin hesap sonuçları Table 10. Calculation results of square cross-sectional column models according to Saatcioglu and Ravzi model

\begin{tabular}{|c|c|c|c|c|c|c|c|c|c|}
\hline No & Boyuna donatı & Sargı donatısı & $\rho_{s}$ & $\begin{array}{c}\sigma_{2} \\
(\mathrm{MPa})\end{array}$ & $\begin{array}{c}\sigma_{2 e} \\
(\mathrm{MPa})\end{array}$ & $\begin{array}{c}\mathrm{f}_{\mathrm{cc}} \\
(\mathrm{MPa})\end{array}$ & $\varepsilon_{c o c}$ & $\varepsilon_{c 85}$ & $\varepsilon_{c 20}$ \\
\hline S1 & $8 \Phi 20$ & & & 2.86 & 1.91 & 36.97 & 0.0065 & 0.0153 & 0.053 \\
\hline S2 & $8 \Phi 22$ & & & 2.86 & 1.92 & 36.99 & 0.0065 & 0.0153 & 0.053 \\
\hline S3 & $8 Ф 24$ & & & 2.86 & 1.92 & 37.02 & 0.0065 & 0.0153 & 0.053 \\
\hline $\mathrm{S} 4$ & $8 Ф 26$ & & & 2.86 & 1.92 & 37.04 & 0.0065 & 0.0153 & 0.053 \\
\hline S5 & 8Ф28 & & & 2.86 & 1.93 & 37.06 & 0.0065 & 0.0154 & 0.053 \\
\hline S6 & $8 Ф 30$ & $\Phi 8 / 50$ & 0.0068 & 2.86 & 1.93 & 37.09 & 0.0065 & 0.0154 & 0.053 \\
\hline S7 & 8Ф32 & & & 2.86 & 1.94 & 37.11 & 0.0065 & 0.0154 & 0.053 \\
\hline S8 & 8Ф34 & & & 2.86 & 1.94 & 37.14 & 0.0065 & 0.0154 & 0.053 \\
\hline S9 & 8Ф36 & & & 2.86 & 1.95 & 37.16 & 0.0065 & 0.0154 & 0.053 \\
\hline S10 & 8Ф38 & & & 2.86 & 1.95 & 37.18 & 0.0065 & 0.0154 & 0.054 \\
\hline S11 & $8 \Phi 40$ & & & 2.86 & 1.96 & 37.21 & 0.0065 & 0.0154 & 0.054 \\
\hline
\end{tabular}

\section{ARAŞTIRMA SONUÇLARI ve TARTIŞMA (RESEARCH RESULTS AND DISCUSSION)}

Mander ve diğ. (1988a), Saatçioğlu ve Ravzi (1992) modellerinden elde edilen sargılı beton basınç dayanımlarını karşılaştırmak amacı ile sayısal çalışmalar yapılmıştır. TBDY,(2018)'de verilen koşullara göre incelenen kolon modellerinde farklı boyuna donatı çapı, farklı sargı donatısı çapı ve aralığına sahip betonarme kesitleri Mander ve diğ. (1988a), Saatçioğlu ve Ravzi (1992) modellerine göre sargılı basınç dayanımları hesaplanmıştır. Farklı sargı donatı çapı ve aralığı için Mander ve diğ. (1988a), Saatçioğlu ve Ravzi (1992) modelleri kullanılarak betonun gerilme şekil değiştirme grafikleri elde edilmiştir. Modeller için yapılan hesap sonuçları Çizelgeler halinde özetlenmiştir. Kare en-kesitli betonarme kolon modellerinde Mander ve diğ. (1988a), Saatçioğlu ve Ravzi (1992) modellerine göre hesaplanan sargılı beton dayanımı ve maksimum gerilmeye karşı gelen birim kısalma değerlerinin karşılaştırması Çizelge 11'de verilmiştir. Farklı boyuna donatı oranı, farklı sargı donatısı çapı ve aralıklarında tasarlanan modellerde hesaplanan değerler incelendiğinde çalışma sonucunda aşağıdaki sonuçlar elde edilmiştir. 
Çizelge 11. Kare en-kesitli betonarme kolon modellerinde hesaplanan sonuçların karşılaştırması Table 11. Comparison of calculated results in square cross-section reinforced concrete column models

\begin{tabular}{|c|cccccc|}
\hline \multirow{2}{*}{ No } & Boyuna donatı & Sargı donatısı & \multicolumn{3}{c|}{ Mander modeli } & \multicolumn{2}{c|}{ Saatçioğlu modeli } \\
& & & $\mathrm{f}_{\mathrm{cc}}^{\prime}(\mathrm{MPa})$ & $\varepsilon_{\mathrm{cc}}$ & $\mathrm{f}_{\mathrm{cc}}(\mathrm{MPa})$ & $\varepsilon_{\mathrm{coc}}$ \\
\hline \multirow{6}{*}{$\mathrm{S} 1$} & \multirow{4}{*}{8920} & & 37.27 & 0.0066 & 36.97 & 0.0065 \\
& & $\Phi 8 / 75$ & 33.32 & 0.0051 & 33.69 & 0.0052 \\
& & $\Phi 8 / 100$ & 31.18 & 0.0042 & 31.95 & 0.0045 \\
& & $\Phi 10 / 50$ & 42.72 & 0.0088 & 39.33 & 0.0074 \\
& & $\Phi 10 / 75$ & 37.20 & 0.0066 & 35.38 & 0.0058 \\
& & $\Phi 12 / 50$ & 48.57 & 0.0110 & 41.63 & 0.0083 \\
& & $\Phi 12 / 75$ & 41.53 & 0.0083 & 37.02 & 0.0065 \\
& & $\Phi 12 / 100$ & 37.48 & 0.0067 & 34.57 & 0.0055 \\
\hline
\end{tabular}

Kare en-kesitli betonarme kolon modellerinde Mander ve diğ. (1988a), Saatçioğlu ve Ravzi (1992) modellerine göre gerilme-şekil değiştirme grafikleri elde edilmiştir. Kare en-kesitli betonarme kolonların Mander ve diğ. (1988a), Saatçioğlu ve Ravzi (1992) modellerine göre gerilme-şekil değiştirme grafiklerinin karşılaştııılması Şekil 13'te karşılaştırmalı olarak verilmiştir.
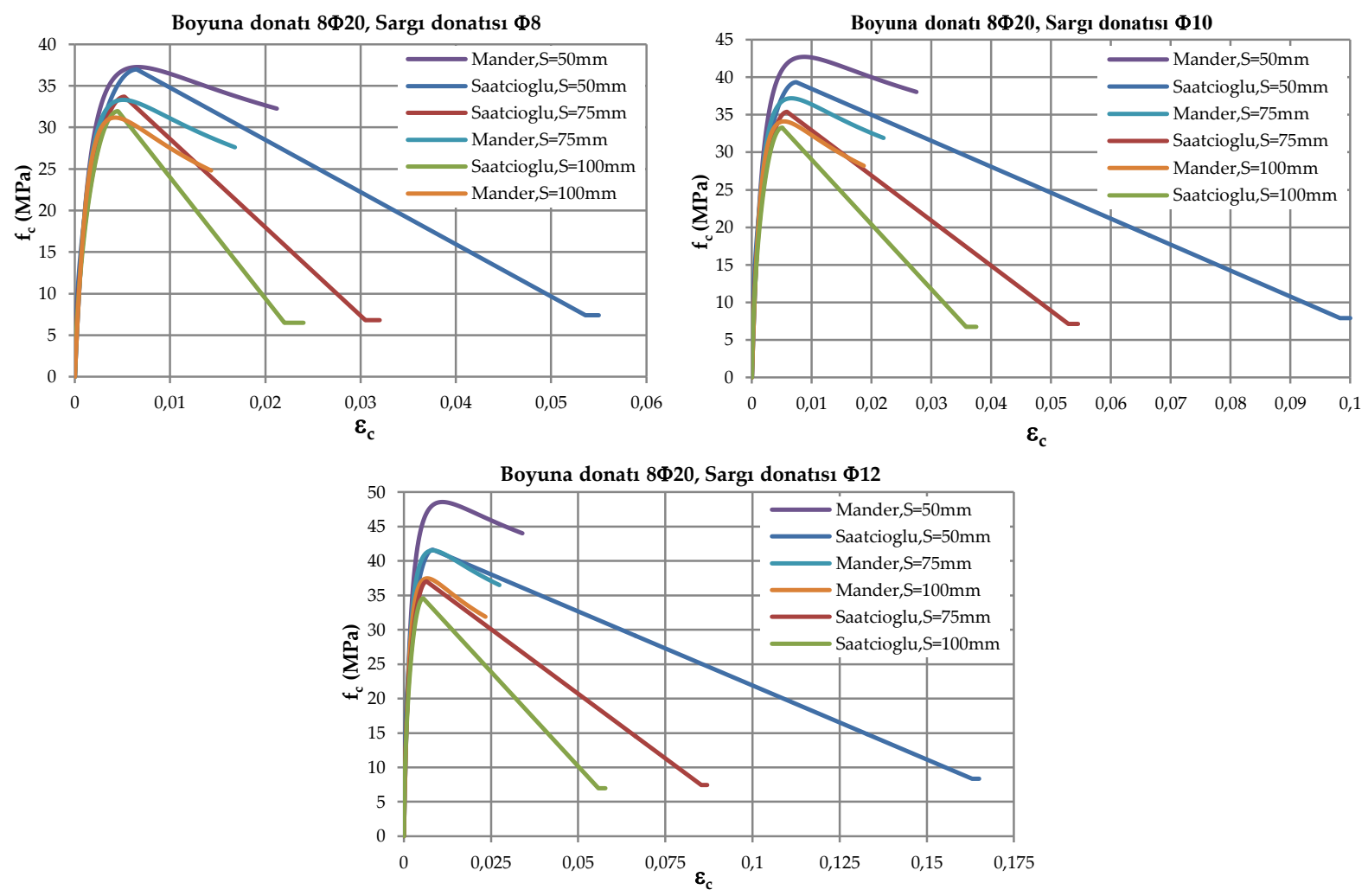

Şekil 13. Kare en-kesitli betonarme kolonların Mander, Saatçioğlu ve Ravzi modellerine göre gerilmeşekil değiştirme grafiklerinin karşılaş̧ırılması

Figure 13. Comparison of stress-strain curves of square cross-section reinforced concrete columns according to Mander, Saatcioglu and Ravzi models

Dairesel en-kesitli betonarme kolon modellerinde Mander ve diğ. (1988a), Saatçioğlu ve Ravzi (1992) modellerine göre hesaplanan sargılı beton dayanımı ve maksimum gerilmeye karşı gelen birim kısalma değerlerinin karşılaştırması Çizelge 12' de verilmiştir. 
Çizelge 12. Dairesel en-kesitli betonarme kolon modellerinde hesaplanan sonuçların karşılaştırması Table 12. Comparison of calculated results in circular cross-section reinforced concrete column models

\begin{tabular}{|c|cccccc|}
\hline \multirow{2}{*}{ No } & \multirow{2}{*}{ Boyuna donatı } & Sargı donatısı & \multicolumn{2}{c|}{ Mander modeli } & \multicolumn{3}{c|}{ Saatçioğlu modeli } \\
& & & $\mathrm{f}_{\mathrm{cc}}^{\prime}(\mathrm{MPa})$ & $\varepsilon_{\mathrm{cc}}$ & $\mathrm{f}_{\mathrm{cc}}(\mathrm{MPa})$ & $\varepsilon_{\mathrm{coc}}$ \\
\hline \multirow{5}{*}{$\mathrm{CR} 1$} & \multirow{3}{*}{$10 \Phi 20$} & $\Phi 8 / 50$ & 35.24 & 0.0085 & 35.73 & 0.0060 \\
& & $\Phi 8 / 75$ & 32.12 & 0.0046 & 32.80 & 0.0048 \\
& & $\Phi 8 / 100$ & 30.45 & 0.0039 & 31.25 & 0.0042 \\
& & $\Phi 10 / 50$ & 39.83 & 0.0076 & 40.36 & 0.0078 \\
& & $\Phi 10 / 75$ & 35.42 & 0.0059 & 36.12 & 0.0061 \\
& & $\Phi 12 / 50$ & 44.82 & 0.0095 & 45.69 & 0.0099 \\
& & $\Phi 12 / 75$ & 39.12 & 0.0073 & 39.92 & 0.0076 \\
& & $\Phi 12 / 100$ & 35.91 & 0.0060 & 36.85 & 0.0064 \\
\hline
\end{tabular}

Dairesel en-kesitli betonarme kolonların Mander ve diğ. (1988a), Saatçioğlu ve Ravzi (1992) modellerine göre gerilme-şekil değiştirme grafiklerinin karşılaştırılması Şekil 14'te karşılaştırmalı olarak verilmiştir.
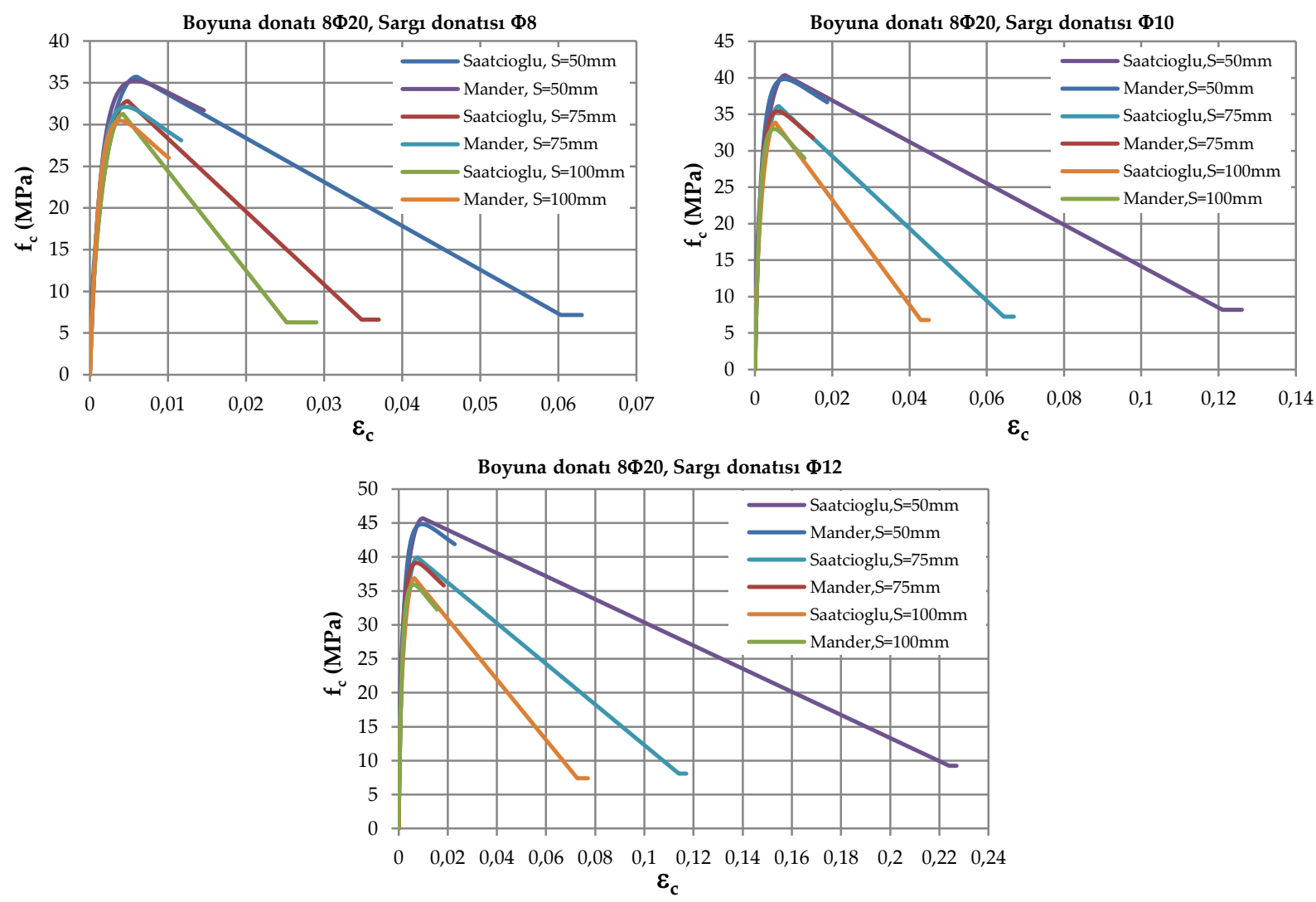

Şekil 14. Dairesel en-kesitli betonarme kolonların Mander, Saatçioğlu ve Ravzi modellerine göre gerilme-şekil değiştirme grafiklerinin karşılaştırılması

Figure 14. Comparison of stress-strain curves of circular cross-section reinforced concrete columns according to Mander, Saatcioglu and Ravzi models

Dikdörtgen en-kesitli betonarme kolon modellerinde Mander ve diğ. (1988a), Saatçioğlu ve Ravzi (1992) modellerine göre hesaplanan sargılı beton dayanımı ve maksimum gerilmeye karşı gelen birim kısalma değerlerinin karşılaştırması Çizelge 13'de verilmiştir. 
Çizelge 13. Dikdörtgen en-kesitli betonarme kolon modellerinde hesaplanan sonuçların karşılaştırması Table 13. Comparison of calculated results in rectangular cross-section reinforced concrete column models

\begin{tabular}{|c|cccccc|}
\hline \multirow{2}{*}{ No } & Boyuna donatı & Sargı donatısı & \multicolumn{3}{c|}{ Mander modeli } & \multicolumn{3}{c|}{ Saatçioğlu modeli } \\
& & & $\mathrm{f}_{\mathrm{cc}}^{\prime}(\mathrm{MPa})$ & $\varepsilon_{\mathrm{cc}}$ & $\mathrm{f}_{\mathrm{cc}}(\mathrm{MPa})$ & $\varepsilon_{\mathrm{coc}}$ \\
\hline \multirow{6}{*}{ REC1 } & \multirow{3}{*}{$10 \Phi 20$} & & 42.55 & 0.0087 & 41.04 & 0.0081 \\
& & $\Phi 8 / 50$ & 36.83 & 0.0064 & 36.60 & 0.0063 \\
& & $\Phi 8 / 75$ & 34.63 & 0.0052 & 34.24 & 0.0054 \\
& & $\Phi 10 / 50$ & 49.84 & 0.0115 & 44.28 & 0.0093 \\
& & $\Phi 10 / 100$ & 37.68 & 0.0068 & 36.06 & 0.0061 \\
& & $\Phi 12 / 50$ & 57.34 & 0.0145 & 47.44 & 0.0106 \\
& & $\Phi 12 / 75$ & 47.91 & 0.0108 & 41.17 & 0.0081 \\
& & $\Phi 12 / 100$ & 42.19 & 0.0085 & 37.84 & 0.0068 \\
\hline
\end{tabular}

Dikdörtgen en-kesitli betonarme kolonların Mander ve diğ. (1988a), Saatçioğlu ve Ravzi (1992) modellerine göre gerilme-şekil değiştirme grafiklerinin karşılaştırılması Şekil 15'te karşılaştırmalı olarak verilmiştir.


Şekil 15. Dikdörtgen en-kesitli betonarme kolonların Mander, Saatçioğlu ve Ravzi modellerine göre gerilme-şekil değiştirme grafiklerinin karşılaştırılması

Figure 15. Comparison of stress-strain curves of rectangular cross-section reinforced concrete columns according to Mander, Saatcioglu and Ravzi models 
Kare en-kesitli betonarme kolon modellerinde farklı boyuna donatı oranı için Mander ve diğ. (1988a), Saatçioğlu ve Ravzi (1992) modellerine göre hesaplanan sargılı beton dayanımı ve maksimum gerilmeye karşı gelen birim kısalma değerlerinin karşılaştırması Çizelge 14'te verilmiştir.

Çizelge 14. Kare en-kesitli betonarme kolon modellerinde hesaplanan sonuçların karşılaştırması Table 14. Comparison of calculated results in square cross-section reinforced concrete column models

\begin{tabular}{|c|c|c|c|c|c|c|}
\hline \multirow{2}{*}{ No } & \multirow{2}{*}{ Boyuna donatı } & \multirow{2}{*}{ Sargı donatısı } & \multicolumn{2}{|c|}{ Mander modeli } & \multicolumn{2}{|c|}{ Saatçioğlu modeli } \\
\hline & & & $\mathrm{f}_{\mathrm{cc}}^{\prime}(\mathrm{MPa})$ & $\varepsilon_{\mathrm{cc}}$ & $\mathrm{f}_{\mathrm{cc}}(\mathrm{MPa})$ & $\varepsilon_{\mathrm{coc}}$ \\
\hline S1 & $8 \Phi 20$ & & 37.27 & 0.0066 & 36.97 & 0.0065 \\
\hline S2 & $8 \Phi 22$ & & 37.39 & 0.0067 & 36.99 & 0.0065 \\
\hline S3 & $8 \Phi 24$ & & 37.52 & 0.0067 & 37.02 & 0.0065 \\
\hline $\mathrm{S} 4$ & $8 \Phi 26$ & & 37.65 & 0.0068 & 37.04 & 0.0065 \\
\hline S5 & $8 \Phi 28$ & & 37.78 & 0.0068 & 37.06 & 0.0065 \\
\hline S6 & $8 \Phi 30$ & $\Phi 8 / 50$ & 37.92 & 0.0069 & 37.09 & 0.0065 \\
\hline S7 & $8 Ф 32$ & & 38.05 & 0.0069 & 37.11 & 0.0065 \\
\hline S8 & $8 Ф 34$ & & 38.19 & 0.0070 & 37.14 & 0.0065 \\
\hline S9 & 8Ф36 & & 38.33 & 0.0070 & 37.16 & 0.0065 \\
\hline S10 & $8 Ф 38$ & & 38.47 & 0.0071 & 37.18 & 0.0065 \\
\hline S11 & $8 \Phi 40$ & & 38.62 & 0.0071 & 37.21 & 0.0065 \\
\hline
\end{tabular}

Yapılan hesapların sonucunda sargı donatı çapının ve sargı donatı aralığının sargılı beton basınç dayanımı ve sünekliği üzerinde etkili olduğu görülmüştür. Tüm modeller için özellikle sargı donatısı oranının betonarme kolon kesitlerin yanal sarg1 basıncının üzerinde etkili olduğu görülmüştür. Sarg1 donatı aralığının sıklaşması kesitin sünekliği ve taşıma kapasitesi üzerinde daha fazla etkiye sahiptir. Betonarme kesitin gerçek davranışı görmek için sargı donatısı oranını dikkate alan beton modeli kullanılmalıdır. Sargı donatısı oranının artması kesitin sünekliğini ve yanal sargı basıncını arttırmaktadır.

Farklı geometri ve parametrelerde tasarlanan betonarme kolon modellerinin Mander ve diğ. (1988a), Saatçioğlu ve Ravzi (1992) modellerine göre hesaplanan sargılı beton dayanımı ve maksimum gerilmeye karşı gelen birim kısalma değerlerinin karşılaştırması Şekil 13, 14, 15 ve Çizelge 11, 12, 13'te verilmiştir. Kare en-kesitli betonarme kolon modellerinde farklı sargı donatısı oranı ve aralığına göre Mander ve diğ. (1988a), Saatçioğlu ve Ravzi (1992) modellerinden elde edilen sonuç değerlerin karşılaştırmasından, sargılı beton basınç dayanımlarında farklılık görülmektedir. Kare en-kesitli betonarme kolon modellerinde 8mm sarg1 donatısı çapı ve 50mm sarg1 donatısı aralığı için Mander ve diğ. (1988a) ve Saatçioğlu ve Ravzi (1992) modellerinden hesaplanan sargılı beton basınç dayanımları arasındaki fark fazladır. Şekil 13 ve Çizelge 11'den görüleceği gibi sargı donatı aralığının artması ile her iki model için hesaplanan sargılı beton basınç dayanımındaki farklar azalmaktadır. Sargı donatısı aralığı sabit iken sargı donatı çapının artması ile her iki modele göre hesaplanan sargılı beton basınç dayanımlarının arasındaki farkların artmakta olduğu sonucu elde edilmiştir (Şekil 13 ve Çizelge 11).

Dairesel en-kesitli kolon modellerinde farklı sargı donatısı oranı ve aralığına göre Mander ve diğ. (1988a), Saatçioğlu ve Ravzi (1992) modellerinden elde edilen sonuç değerlerin karşılaştırmasından sargılı beton basınç dayanımlarında farklılıkların ihmal edilebilecek düzeyde olduğu görülmektedir. Dairesel en-kesitli kolon modellerinde sargı donatı aralığı ve sargı donatısı çapının değişmesi durumunda her iki modele göre hesaplanan sargılı beton basınç dayanımlarının arasında oluşan farklılıkların çok az olduğu sonucu elde edilmiştir (Şekil 14 ve Çizelge 12).

Dikdörtgen en-kesitli betonarme kolon modellerinde farklı sargı donatısı oranı ve aralığına göre Mander ve diğ. (1988a), Saatçioğlu ve Ravzi (1992) modellerinden elde edilen sonuç değerlerin karşılaştırmasından, sargılı beton basınç dayanımlarında farklılıkların oluştuğu görülmektedir. Dikdörtgen en-kesitli kolon modellerinde 50mm sargı donatı aralığı için Mander ve diğ. (1988a), Saatçioğlu ve Ravzi (1992) modellerinden hesaplanan sargılı beton basınç dayanımları arasındaki farklılıkların büyük olduğu görülmektedir. Betonarme kolon kesitlerinde sabit sargı donatısı çapı için artan sargı donatısı aralığına göre her iki model için hesaplanan sargılı beton basınç dayanımları 
arasındaki farkların azaldığı görülmektedir. Betonarme kolon kesitlerinde sabit sargı donatısı aralığı için, sarg1 donatısı çapının artması ile Mander ve diğ. (1988a), Saatçioğlu ve Ravzi (1992) modellerinden hesaplanan sargılı beton basınç dayanımları arasındaki farkların artmakta olduğu sonucu elde edilmiştir (Şekil 15 ve Çizelge 13).

Tasarlanan betonarme kolon kesitlerinde boyuna donatı oranının sargılı beton basınç dayanımına etkisini araştırmak için kare en-kesitli betonarme kolon modellerinde farklı boyuna donatı oranı için Mander ve diğ. (1988a), Saatçioğlu ve Ravzi (1992) modellerine göre hesaplanan sargılı beton dayanımı ve maksimum gerilmeye karşı gelen birim kısalma değerlerinin karşılaştırması Çizelge $14^{\prime}$ te verilmiştir. Sonuçlardan görüleceği gibi sabit sargı donatısı çapı ve aralığı için, boyuna donatı oranının değişmesi her iki modelde de sargılı beton basınç dayanımında ihmal edilebilecek düzeyde farklılıklar oluşturmuştur.

\section{SONUÇ (RESULTS)}

Sayısal çalışmalarda farklı geometri ve parametrelerde tasarlanan kolon modellerinden elde edilen sonuçların karşılaştırılması Çizelgeler ve Şekiller halinde özetlenerek sunulmuştur. Modellerde kullanılan sargı donatısının akma dayanımları sabit olsa da farklı çaplarda ve aralıklarda sargı donatısı kullanımının, farklı geometride tasarlanan betonarme kolon kesitlerinin yanal basınç dayanımını etkilediği sonucu elde edilmiştir. Sargı donatı sayısı (x ve y yönünde sargı donatı kol sayısı) veya sargı donatı oranının artırılmasının aynı etkiyi yaratması beklenmelidir, dolayısıyla sargı donatısı artıııldığında da kesit taşıma gücü artması olağandır. Sargı donatı aralığı azaltıldıkça ve sargı donatısı çapı arttıkça, sargı etkisi dolayısı ile süneklilik artmaktadır.

Farklı geometri ve parametrelerde tasarlanan betonarme kolon modellerinin Mander ve diğ. (1988a), Saatçioğlu ve Ravzi (1992) modellerine göre hesaplanan sargılı beton dayanımı ve maksimum gerilmeye karşı gelen birim kısalma değerlerinin farklı olduğu sonucu elde edilmiştir. Dairesel en-kesitli betonarme kolon kesitlerinde her iki modelden hesaplanan sargılı beton basınç dayanımlarında yakın sonuçlar elde edilmiştir. Hesaplanan sargılı beton basınç dayanımları arasındaki fark, kare ve dikdörtgen en-kesitli kolon modellerinde dairesel en-kesitli kolon modeline göre daha fazla olduğu görülmektedir. Tasarlanan betonarme kolon modellerinde her iki modele göre hesaplanan sargılı beton dayanımlarında en çok fark, dikdörtgen en-kesitli kolon modellerinde elde edilmiştir. Mander ve diğ. (1988a), Saatçioğlu ve Ravzi (1992) modellerinde sargılı beton basınç dayanımları arasındaki farklar, kolon kesitlerindeki sargı donatısı çapı ve aralığına göre değişmektedir. Bu farklılıklar sargı donatı çapının artması ile artmakta ve sargı donatısı aralığının artması ile azalmaktadır. $8 \mathrm{~mm}$ çapındaki sargı donatısı için sargılı beton basınç dayanımları arasındaki farklar azalmakta ve $50 \mathrm{~mm}$ sargı donatısı aralığı için iki modelden elde edilen farklar artmaktadır. Sabit sargı donatısı çapı ve aralığı için tasarlanan betonarme kolon modellerinde farklı boyuna donatı oranları için Mander ve diğ. (1988a), Saatçioğlu ve Ravzi (1992) modellerinden hesaplanan sargılı beton basınç dayanımları arasında ihmal edilecek kadar küçük farklılıklar görülmüştür. Boyuna donatı oranının artması sargılı beton basınç dayanımı, maksimum gerilmeye karşı gelen birim kısalma ve kolon kesitlerinin sünekliğinde önemli etkiye sahip olmadığı görülmüştür.

\section{KAYNAKLAR (REFERENCES)}

Canbay, E., Ersoy, U., Özcebe, G., Sucuoğlu, H., Wasti, S. T., 2010, Binalar İçin Deprem Mühendisliği Temel Ilkeler, ISBN: 9799789944070, ODTÜ, Akademik Kitaplar Yayınevi, Ankara. 
Ersoy, U., Özcebe, G., 2012, Betonarme 1, İSBN: 978-975-503-215-31, Evrim Yayınevi ve Bilgisayar San. Tic. Ltd. Şti, İstanbul.

Foroughi, S., 2018, Sargılı ve Sargısız Betonarme Elemanların Davranışlarının Gerilme-Şekil Değiştirme Modellerinin Araştırılması, Doktora Semineri, Selçuk Üniversitesi, Fen Bilimleri Enstitüsü, Konya/Türkiye.

Hognestad, E., 1951, "A study of combined bending and axial load in reinforced concrete members", University of Illinois Engineering Exp. Station. Bulletin. Vol. 49, No. 22.

Mander, J. B., 1983, Seismic design of bridge piers, PhD Thesis, University of Canterbury, Christchurch, New Zealand.

Mander, J. B., Priestley, M. J. N. and Park, R., 1988a, "Theoretical stress-strain model for confined concrete", Journal of Structural Engineering, Vol. 114, No. 8, pp.1804-1826.

Mander, J. B., Priestley, M. J. N. Park, R. , 1988b, “Observed stress-strain behavior of confined concrete”, Journal of Structural Engineering. Vol. 114, No. 8, pp. 1827-1849.

Saatcioglu, M., Ravzi, S. R., 1992, "Strength and ductılity of confined concrete", Journal of Structural Engineering, Vol. 118, No. 6, pp.1590-1607.

TBDY, 2018, Türkiye Bina Deprem Yönetmeliği, T.C. Bayındırlık ve İskân Bakanlığı, Ankara.

TS500, 2000, Betonarme Yapıların Tasarım ve Yapım Kuralları, Türk Standardları Enstitüsü, TSE, Ankara. 